\title{
Geology of the Central Roan Plateau Area, Northwestern Colorado
}

\section{U.S. GEOLOGICAL SURVEY BULLETIN 1787-R}

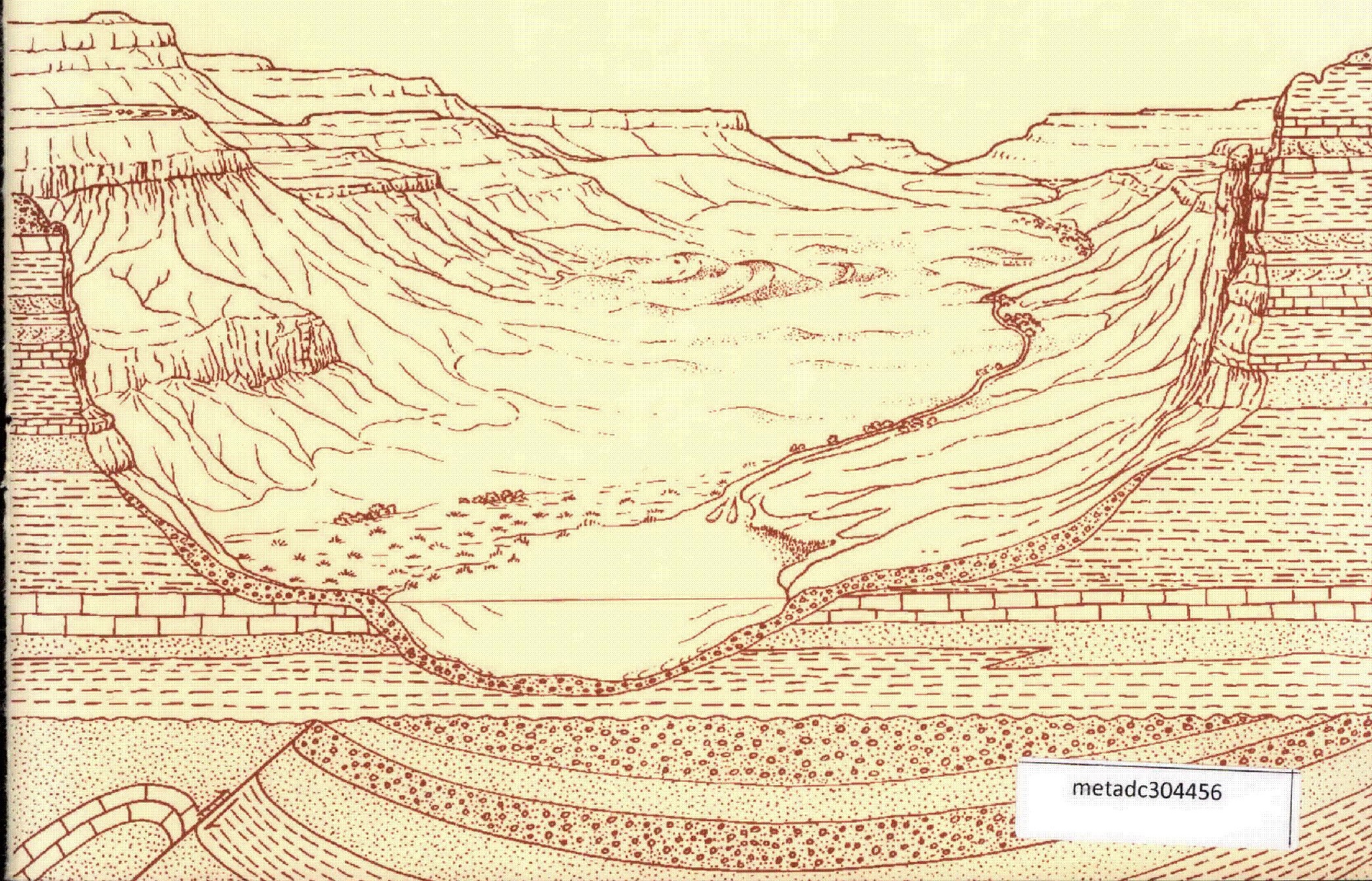


U.S. Geological Survey bulletin

Recelved on: 12-10-92

Caltech Libraries 
Chapter R

\title{
Geology of the Central Roan Plateau Area, Northwestern Colorado
}

\author{
By WILLIAM J. HAIL, JR.
}

A multidisciplinary approach to research studies of sedimentary rocks and their constituents and the

evolution of sedimentary basins, both ancient and modern

U.S. GEOLOGICAL SURVEY BULLETIN 1787

EVOLUTION OF SEDIMENTARY BASINS—UINTA AND PICEANCE BASINS 


\title{
U.S. DEPARTMENT OF THE INTERIOR
}

MANUEL LUJAN, JR., Secretary

\author{
U.S. GEOLOGICAL SURVEY \\ Dallas L. Peck, Director
}

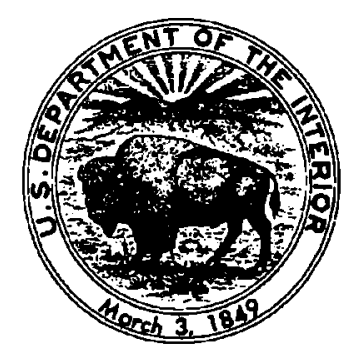

Any use of trade, product, or firm names in this publication is for descriptive purposes only and does not imply endorsement by the U.S. Government.

For sale by the

Books and Open-File Reports Section

U.S. Geological Survey

Federal Center

Box 25425

Denver, CO 80225

\section{Library of Congress Cataloging-in-Publication Data}

Hail, William James, 1922

Geology of the central Roan Plateau area, northwestern Colorado / by William J. Hail, Jr.

p. cm. - (U.S. Geological Survey bulletin ; 1787-R)

Includes bibliographical references ( $p$.)

Supt. of Docs. no.: I 19.3:1787-R

1. Geology-Colorado-Roan Plateau Region. I. Title. II. Series. III. Series:

Evolution of sedimentary basins--Uinta and Piceance basins ; ch. R.

QE75.B9 no. 1787-R

[QE92.R56]

$557.3 \mathrm{~s}-\mathrm{dc} 20$

[557.88'16]

90-23063 


\section{CONTENTS}

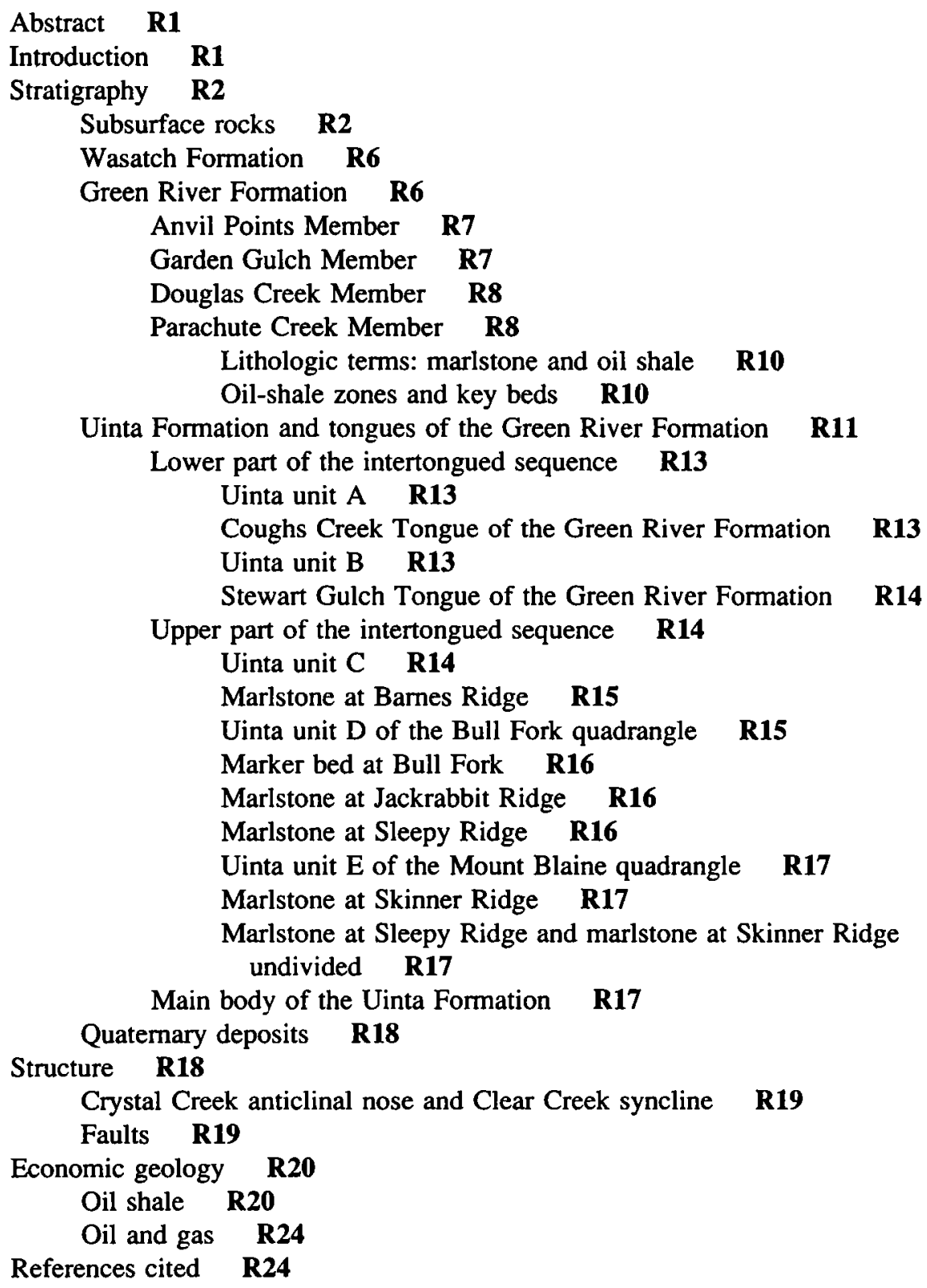

\section{PLATES}

[Plates are in pocket]

1. Correlation of selected stratigraphic units of Eocene Green River and Uinta Formations in the eastern part of the central Roan Plateau area, northwestern Colorado.

2. Correlation of oil-shale zones in selected drill holes the central Roan Plateau area, northwestern Colorado. 
FIGURES

1-2. Maps showing:

1. Location of central Roan Plateau area, Piceance Creek basin R2

2. Generalized geology of central Roan Plateau area R3

3. Measured section of part of Green River Formation R9

4-7. Charts showing correlation of mapped uints in intertongued sequence of mapped units of Green River and Uinta Formations between:

4. Bull Fork and Cutoff Gulch quadrangles R11

5. Mount Blaine and Circle Dot Gulch quadrangles $\quad$ R12

6. Bull Fork and western part of Mount Blaine quadrangles $\quad$ R12

7. Cutoff Gulch and Circle Dot Gulch quadrangles R13

8. Map showing structure of central Roan Plateau area $\quad$ R19

\section{TABLES}

1. Description of subsurface rocks penetrated by drilling, central Roan Cliffs area $\mathbf{R 4}$

2. Summary description of exposed bedrock units, central Roan Plateau area R5

3-6. Oil-shale resources in the:

3. Bull Fork quadrangle $\mathbf{R 2 0}$

4. Cutoff Gulch quadrangle R20

5. Mount Blaine quadrangle R21

6. Circle Dot Gulch quadrangle R21

7. Oil-shale test drill holes, central Roan Plateau area $\quad$ R22

8. Oil and gas drill holes, central Roan Plateau area R25 


\title{
Geology of the Central Roan Plateau Area, Northwestern Colorado
}

\author{
By William J. Hail, Jr.
}

\begin{abstract}
The central Roan Plateau area comprises four $71 / 2$-minute quadrangles, an area of about $230 \mathrm{mi}^{2}\left(596 \mathrm{~km}^{2}\right)$ in the south-central part of the Piceance Creek basin in northwestern Colorado, about $20 \mathrm{mi}(32 \mathrm{~km})$ west of the town of Rifle. Subsurface rocks penetrated by drill holes aggregate as much as $8,500 \mathrm{ft}(2,600 \mathrm{~m})$ in thickness and include (in ascending order) the upper part of the Mancos Shale and the Mesaverde Formation of Late Cretaceous age, the main body of the Wasatch Formation of Paleocene and Eocene age, the Cow Ridge Member of the Green River Formation of Eocene age, and a tongue of the Wasatch Formation of Eocene age. A regional unconformity separates Cretaceous rocks from Tertiary rocks. Exposed rocks aggregate as much as 4,550 ft $(1,400$ $\mathrm{m}$ ) in thickness and include (in ascending order) the upper part of the Wasatch Formation and a tongue of the Wasatch, of Eocene age, the Anvil Points, Garden Gulch, Douglas Creek, and Parachute Creek Members of the Green River Formation, of Eocene age, an intertongued sequence of the Green River and Uinta Formations of Eocene age, and the Uinta Formation of Eocene age. Surficial deposits of Quaternary age (Pleistocene and Holocene) include alluvium, talus, slopewash, and landslides.

Exposed rocks of the Wasatch Formation, including an upper tongue of the Wasatch, consist mostly of varicolored fluvial claystone and channel sandstone. The Eocene Green River Formation consists almost entirely of rocks of lacustrine origin and is divided into four members. The lowermost westward-thinning Anvil Points Member is mostly near-shore freshwater lacustrine kerogen-rich fissile shale and finegrained sandstone. The Garden Gulch Member is freshwater lacustrine gray to brown dolomitic shale and claystone and lesser fissile clay shale. The Douglas Creek Member is nearshore freshwater lacustrine silty dolomitic shale and claystone, clay shale, and lesser siltstone, sandstone, oil shale, and algal limestone. The Parachute Creek Member is mostly dolomitic
\end{abstract}

Manuscript approved for publication October 9, 1990. marlstone, much of which is oil shale, lesser clay shale, siltstone, and sandstone, and several very thin altered tuff beds. The youngest Tertiary formation is the Uinta Formation, a heterogeneous sequence of clastic sediments deposited in a generally southward-prograding fluvial-deltaic complex that ultimately filled Eocene Lake Uinta in the Piceance Creek basin. The Uinta and Green River Formations are complexly intertongued.

The area is on the southwestern flank of the Piceance Creek basin. The generally north to northeast dip of the rocks is interrupted by a low-amplitude fold system consisting of the northwest-trending Crystal Creek anticlinal nose and the Clear Creek syncline. There are no major faults in the area.

The area contains major oil-shale resources, estimated to be about 120 billion barrels in beds below the top of the Mahogany oil-shale zone. Additional resources exceeding 40 billion barrels may be present above the Mahogany zone. Most of the oil-shale resources are in the Parachute Creek Member of the Green River Formation.

There has been no oil or gas production from several test drill holes.

\section{INTRODUCTION}

The central Roan Plateau is in Garfield and Rio Blanco Counties of northwestern Colorado, about $20 \mathrm{mi} \mathrm{(32}$ $\mathrm{km}$ ) west of the town of Rifle (fig. 1). The report area comprises the Bull Fork, Cutoff Gulch, Mount Blaine, and Circle Dot Gulch 71/2-minute quadrangles, an area of about $230 \mathrm{mi}^{2}\left(596 \mathrm{~km}^{2}\right)$. Much of the area occupies the high ground of the Roan Plateau in the southern part of the Piceance Creek basin and includes the major drainage divide between the Colorado and White Rivers. Maximum plateau elevations are about $7,000 \mathrm{ft}(2,130 \mathrm{~m})$. The southern part of the area is cut by deep canyons along Parachute Creek and its tributaries and by Clear Creek and its tributaries. Relief between the plateau and the canyon floors is about $1,500-2,600 \mathrm{ft}(460-790 \mathrm{~m})$. From the north, a network of dirt roads gives access to the plateau area from 


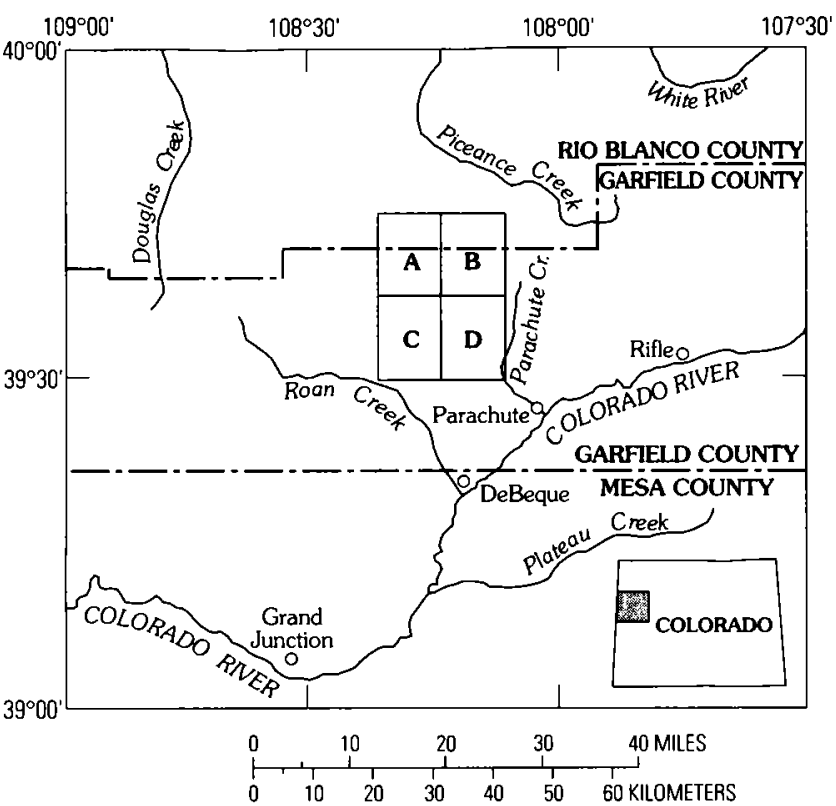

Figure 1. Location of the central Roan Plateau area (shaded), Piceance Creek basin, northwestern Colorado. Quadrangles: A, Bull Fork; B, Cutoff Gulch; C, Mount Blaine; D, Circle Dot Gulch.

a paved road along Piceance Creek. From the south, graded roads give access to the canyons from the towns of Parachute and DeBeque. The climate is semiarid. Natural vegetation is mostly sagebrush, pinyon pine, juniper, and, in the higher parts of the plateau, abundant groves of aspen. Hay is grown along irrigated valleys. Cattle-raising is essentially the only commercial activity in the area. About 45 percent of the land is owned by the Federal Government; the rest is privately owned. Most of the Federally owned land is in the northern part of the report area; about 60 percent of this land is subject to oil-shale patent claims.

Geologic mapping of this area was begun in 1974 as part of a larger program of detailed geologic mapping on 71/2-minute (1:24,000 scale) topographic base maps, undertaken chiefly because of a renewed interest in oil-shale resources of the Piceance Creek basin. The report area is in the south-central part of the Piceance Creek basin, a very deep structural and sedimentary basin that formed during the Laramide orogeny. The area contains large potentially important oil-shale resources. Geologic maps of all four quadrangles comprising the report area (fig. 1) have been published individually, and references in this report are made to the published maps. These four quadrangles are: Bull Fork, MF-830 (Hail, 1977a), Cutoff Gulch, MF-691 (Hail, 1975), Mount Blaine, MF-984 (Hail, 1978), and Circle Dot Gulch, MF-1293 (Hail, 1982). Some modifications to the various stratigraphic units shown on the individual maps were made during the compilation of a 1:50,000-scale map of these and four other quadrangles (Hail and others, 1989). These modifications were mostly the consolidation of certain map units and elimination of small outcrops of some Quaternary units. Figure 2 is a small-scale generalized geologic map of the report area.

Prior geologic studies of the area have been parts of broader, mostly reconnaissance studies of the Piceance Creek basin. Most of the older work was described by Bradley (1931, p. 2-3) and by Donnell (1961, p. 840). A $1: 62,500$-scale geologic map of the DeBeque area by Waldron and others (1951) includes approximately the southern half of the the report area. A report on the Tertiary geology and oil shale of the Piceance Creek basin by Donnell (1961) includes a planimetric-base 1:125,000-scale geologic map. Since about 1961 , several studies touching on the geology of the central Roan Plateau area have been published and most deal with oil shale.

\section{STRATIGRAPHY}

Subsurface rocks penetrated by drilling in the report area include the uppermost part of the Mancos Shale, and the Mesaverde Formation, both of late Cretaceous age, the Wasatch Formation of Paleocene and Eocene age, and the Cow Ridge Member of the Green River Formation of Eocene age (table 1). Bedrock strata exposed in the report area include the uppermost part of the Wasatch Formation, the Green River Formation, and the Uinta Formation, all of Eocene age (table 2). Surficial deposits are Pleistocene and Holocene in age.

\section{Subsurface Rocks}

Information on subsurface strata in the area is sparse owing to the lack of deep drill holes. The oldest rocks penetrated by drilling are in the uppermost part of the Mancos Shale of Late Cretaceous age. The Mancos Shale is a thick unit of gray to brown shale, entirely offshore marine in origin. The Mancos may exceed $5,000 \mathrm{ft}(1,525 \mathrm{~m})$ in thickness.

Cretaceous rocks overlying the Mancos Shale are included in the Mesaverde Formation of Late Cretaceous (Maastrichtian) age. Equivalent rocks crop out along the Grand Hogback, about $10 \mathrm{mi}(16 \mathrm{~km})$ east of the report area, and consist of the Iles and Williams Fork Formations of the Mesaverde Group (Tweto and others, 1978). Equivalent rocks of the Mesaverde Group cropping out about $20 \mathrm{mi}$ (32 $\mathrm{km}$ ) southwest of the area comprise the Sego Sandstone, Mount Garfield Formation, and Hunter Canyon Formation (Cashion, 1973). Approximately the lower one-third of the Mesaverde Formation (Sego and Mount Garfield, or Iles Formations equivalent) consists of intertongued marine sandstone and shale and nonmarine fluvial and paludal rocks including coal beds. The marine shale beds are regarded as tongues of the Mancos Shale. The upper 


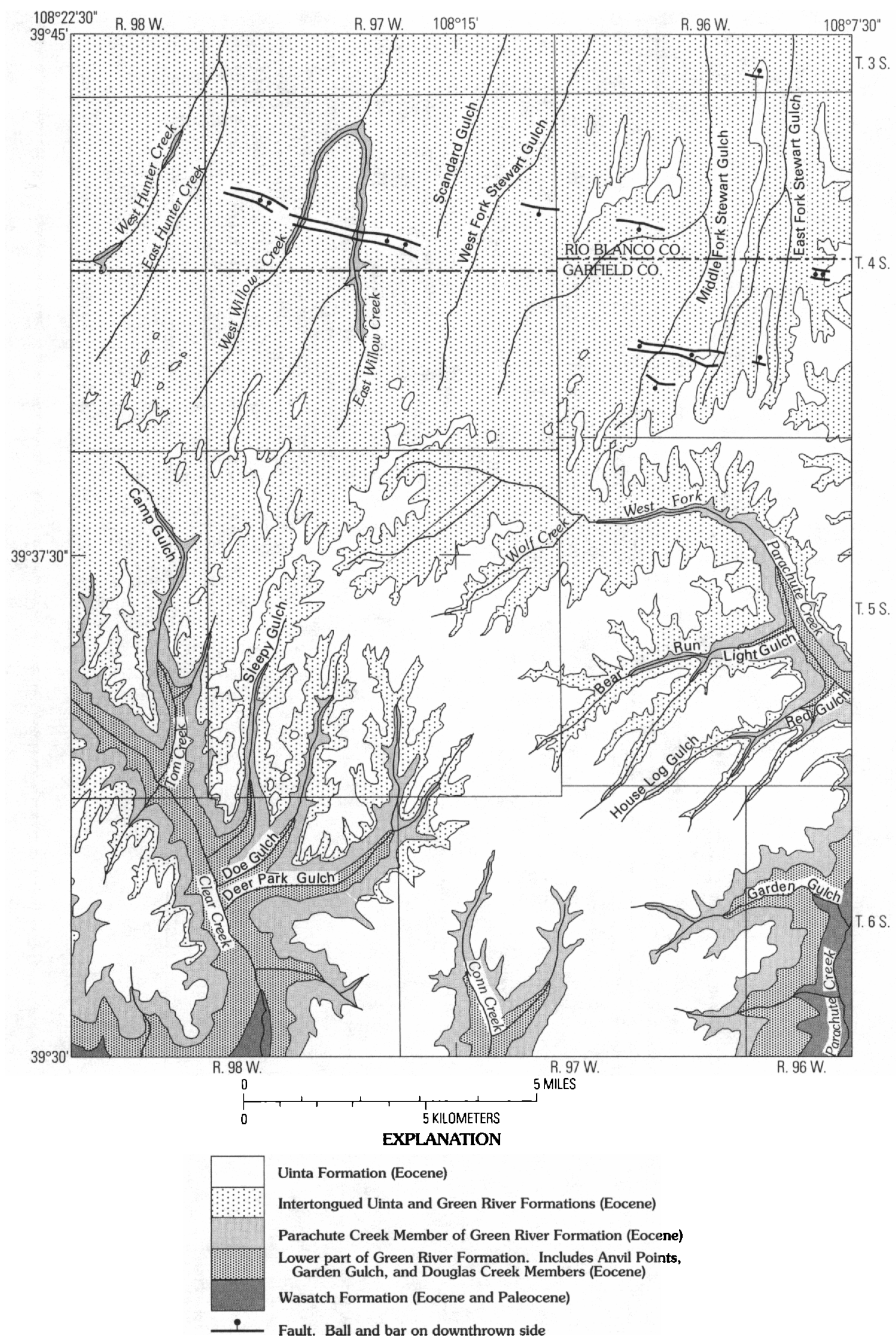

Figure 2. Generalized geology of the central Roan Plateau area. Quaternary deposits are not shown. 
Table 1. Description of subsurface rocks penetrated by drilling, central Roan Cliffs area

\begin{tabular}{|c|c|c|}
\hline \multicolumn{3}{|c|}{ Thickness } \\
\hline (feet) & (meters) & Description \\
\hline Eocene...............................Tongue of Wasatch Formation ............................................100-350 & $30-107$ & $\begin{array}{l}\text { Varicolored red, purple, maroon, yellowish-gray shale and } \\
\text { claystone. Contains some beds of siltstone and fine-to } \\
\text { medium-grained lenticular sandstone. Fluvial. }\end{array}$ \\
\hline Eocene................................... Cow Ridge Member of Green River Formation ............................... & 0-200 & $\begin{array}{l}\text { Dark-gray dolomite; variably ostracodal clay shale; brown, } \\
\text { locally coaly carbonaceous shale; gray to brown siltstone } \\
\text { and sandstone; minor marlstone and ostracodal limestone. } \\
\text { Lacustrine and paludal. }\end{array}$ \\
\hline Eocene and Paleocene ..... Main body of Wasatch Formation........ & $730-1,160$ & $\begin{array}{l}\text { Varicolored red, purple, maroon, gray, grayish-green } \\
\text { claystone, shale, and mudstone; brown to gray siltstone and } \\
\text { lenticular channel sandstone; minor carbonaceous locally } \\
\text { coaly shale, conglomeratic sandstone. Fluvial and paludal. }\end{array}$ \\
\hline Late Cretaceous ................... Mesaverde Formation & 1,000 & $\begin{array}{l}\text { Upper part: lenticular, gray to brown, mostly fine-grained } \\
\text { sandstone; gray to grayish-green claystone and shale; lesser } \\
\text { siltstone, carbonaceous shale, and coal. Fluvial and } \\
\text { paludal. Lower part: lenticular to persistent, gray to brown, } \\
\text { fine-grained sandstone; siltstone; shale; claystone; brown } \\
\text { carbonaceous shale; and coal. Marine, fluvial, and paludal. }\end{array}$ \\
\hline 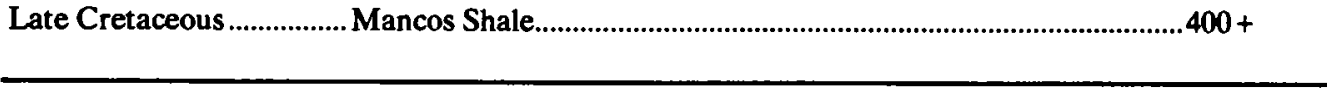 & $120+$ & $\begin{array}{l}\text { Brown to gray shale; minor sandstone and siltstone. } \\
\text { Marine. }\end{array}$ \\
\hline
\end{tabular}


Table 2. Summary description of exposed bedrock units, central Roan Plateau area

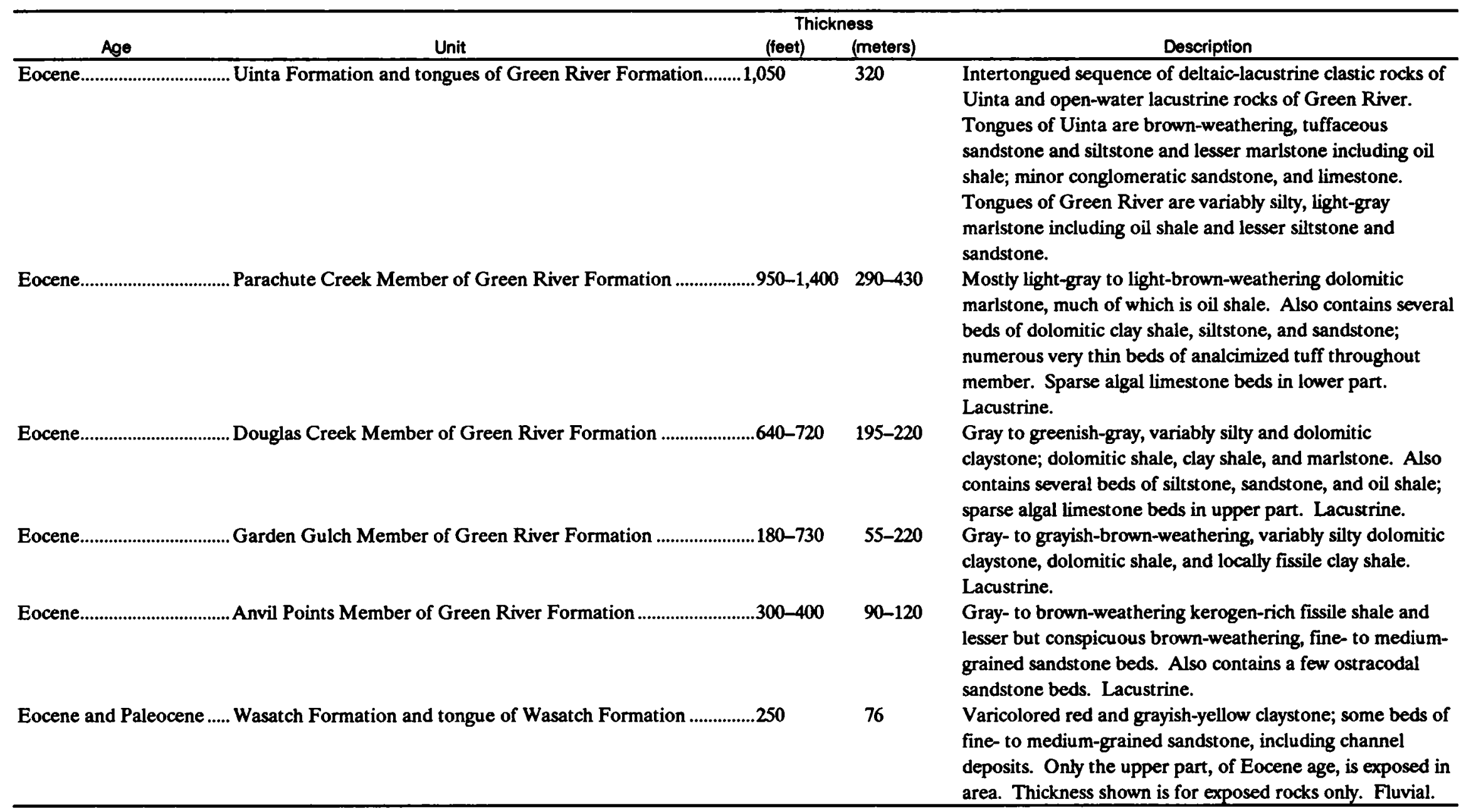


two-thirds of the Mesaverde Formation (Hunter Canyon or Williams Fork Formations equivalent) consists entirely of nonmarine rocks of fluvial and paludal origin, including channel and other fluvial sandstone, claystone, shale, and carbonaceous shale. Coal beds are present in the lower part of the formation.

A widespread regional unconformity separates Cretaceous from Tertiary rocks. The oldest Tertiary unit is the main body of the Wasatch Formation. The lowermost beds of the main body of the Wasatch are late Paleocene in age; higher beds are early to middle Eocene. The Wasatch consists of a heterogeneous sequence of fluvial and paludal rocks including varicolored mudstone, claystone, shale, and carbonaceous shale.

The upper Paleocene part of the Wasatch is approximately equivalent to the upper Paleocene Atwell Gulch Member of the Wasatch (Donnell, 1969) in the southern part of the Piceance Creek basin and to the Fort Union Formation of the lower Yellow Creek area (Hail, 1990) in the northwestern part of the basin.

Overlying the main body of the Wasatch in most of the report area is a sequence of lacustrine, paludal, and fluvial rocks designated by Johnson (1984) as the Cow Ridge Member (lower and middle Eocene) of the Green River Formation. The Cow Ridge represents the earliest evidence of lacustrine deposition in the basin. The unit tongues out into the Wasatch Formation approximately along the eastern edge of the report area (Johnson, 1984, fig. 2).

A tongue of the Wasatch Formation overlies the Cow Ridge Member of the Green River. The Wasatch tongue consists of fluvial varicolored shale and claystone, siltstone, and lenticular channel sandstone. It presumably merges with the main body of the Wasatch near the east boundary of the report area.

\section{Wasatch Formation}

Exposed rocks of the Wasatch Formation, including both the main body and the upper tongue of Wasatch, in the central Roan Plateau consist mostly of varicolored red and grayish-yellow claystone and channel-form beds of fine- to medium-grained sandstone. Only the uppermost $240-250 \mathrm{ft}$ $(73-75 \mathrm{~m})$ of the formation is exposed, near the southern boundary of the area in the valleys of Roan and Clear Creeks near the south end of Skinner Ridge and in the valley of Parachute Creek. The exposures along Roan Creek and Clear Creek are in the upper part of the tongue of the Wasatch Formation inasmuch as the Cow Ridge Member is present in the subsurface. The outcrops along Parachute Creek are in the upper part of the main body of the Wasatch inasmuch as the Cow Ridge Member is absent in this area (Hail and others, 1989).

\section{Green River Formation}

The Green River Formation of Eocene age consists almost entirely of rocks of lacustrine origin deposited in the long-lived Eocene Lake Uinta. The Green River conformably overlies and intertongues with the nonlacustrine fluvial rocks of the Wasatch Formation and is conformably overlain by and intertongues with the upper Eocene Uinta Formation. The main body of the Green River Formation in the central Roan Plateau area includes (in ascending order) the Anvil Points Member, Garden Gulch Member, Douglas Creek Member, and Parachute Creek Member. Within the report area, rocks of the Anvil Points Member are laterally equivalent to the lower part of the Garden Gulch Member, and rocks of the Douglas Creek Member are laterally equivalent to the upper part of the Garden Gulch Member. On a regional basis, the Anvil Points, Garden Gulch, and Douglas Creek are for the most part laterally equivalent, representing different facies of lacustrine deposition. The Long Point Bed, named and described by Johnson (1984, p. 11-16), is a widespread transgressive lacustrine bed that marks the base of the main body of the Green River in the report area and throughout much of the Piceance Creek basin. The Long Point Bed conformably overlies the Wasatch Formation and marks a major expansion of Lake Uinta. The Long Point is a distinctive fossiliferous bed of various lithologic types containing oolites, ostracodes, and gastropods. The bed is from less than $1 \mathrm{ft}(0.3 \mathrm{~m})$ to as much as $12 \mathrm{ft}(3.7 \mathrm{~m})$ thick and is present in the report area at the Wasatch-Garden Gulch contact along Clear Creek and at the Wasatch-Anvil Points contact along Parachute Creek.

In his original definition of the Green River Formation in the Uinta and Piceance Creek basins, Bradley (1931, p. 9-15, pls. 3, 7, and 8) named four members in ascending order, the Douglas Creek, Garden Gulch, Parachute Creek, and Evacuation Creek Members. Bradley (1931, p. 9) stated, "These members persist throughout most of this area, though they vary in thickness and lose their identity where they merge into a shore facies." Later geologic mapping has not substantiated the basinwide extent of these members as proposed by Bradley. Mapping instead shows complex lateral lithologic changes that have resulted in a confusing application of map-unit names, especially for those strata below the Mahogany ledge of the Parachute Creek Member. This problem is shown by a comparison of maps showing the geology in the upper drainages of Parachute, Roan, and Clear Creeks (Waldron and others, 1951; Donnell, 1961; Cashion, 1973; Johnson, 1975, 1977a, 1981a; Hail, 1978, 1982). The area covered by these maps includes all or part of the report area. The treatment of the Garden Gulch and Douglas Creek Members and equivalent strata is especially confusing. 


\section{Anvil Points Member}

In the report area, the Anvil Points Member of the Green River Formation is exposed only along Parachute Creek. The member represents the lowermost part of a westward-thinning wedge of interbedded near-shore lacustrine sandstone and shale. A few miles east of the area in outcrops along the Roan Cliffs, complete replacement of the Garden Gulch Member by the Anvil Points Member reflects an abrupt facies change from offshore to nearshore freshwater lacustrine sedimentation.

Strata comprising the the Anvil Points Member of this report were formerly considered to be part of the Douglas Creek Member of the Green River Formation by Bradley (1931, pls. 3 and 7) along Parachute Creek where it underlies the Garden Gulch Member near its type locality. Several geologic maps followed Bradley's terminology for these units in this area (Duncan and Denson, 1949; Waldron and others, 1951; Cashion, 1973). However, just east of Parachute Creek outside the report area, Duncan and Denson (1949), and Cashion (1973) show the eastward termination of these units where they merge into the unit now termed Anvil Points Member. The eastward gradation of the Garden Gulch into the Anvil Points represents a change where sandstone beds of the Anvil Points pinch out westward, leaving the dominant clay shale of the Garden Gulch Member. Inasmuch as some of the relatively abundant sandstone beds and other rocks of the lower part of the Anvil Points persist westward across Parachute Creek, the name Anvil Points was retained for these beds by Hail (1982), O'Sullivan and Hail (1987), and Hail and others (1989), discontinuing the designation Douglas Creek Member for the unit along Parachute Creek. The name Garden Gulch is retained for the overlying unit.

The Anvil Points Member was first used by Donnell (1953, p. 16) to replace the informal name "lower sandy member of the Green River Formation" that had been used on two geologic maps (Duncan and Denson, 1949; Duncan and Belser, 1950). Johnson (1975) used the term Anvil Points Member for these beds in the Long Point quadrangle just south of the report area where they merge laterally into the Garden Gulch Member by a rather abrupt pinchout of the characteristic Anvil Points sandstone beds.

In the outcrops along Parachute Creek, the Anvil Points Member consists of kerogen-rich gray- to brownweathering fissile clay shale and lesser but conspicuous brown-weathering fine- to medium-grained sandstone beds. The unit also contains a few oolitic sandstone and limestone beds and very minor algal limestone beds. The base of the unit is the Long Point Bed. The Anvil Points Member is entirely of lacustrine origin in the report area. In general the Anvil Points in the report area is a nonresistant unit but contains broken slopes because of several relatively resistant sandstone beds. The brown weathering of these sandstone beds gives the unit a generally brown appearance in contrast to the generally gray weathering of the overlying
Garden Gulch shale beds. The Anvil Points conformably overlies the Wasatch Formation and conformably underlies and interfingers with the Garden Gulch Member of the Green River Formation. The Anvil Points Member is about $360-400 \mathrm{ft}(110-120 \mathrm{~m})$ thick in the report area along Parachute Creek.

\section{Garden Gulch Member}

The Garden Gulch Member was named by Bradley (1931, p. 10) for exposures near the mouth of Garden Gulch, a tributary of Parachute Creek in the report area. The precise location of Bradley's (1931, pl. 7) measured type section of the Garden Gulch Member is not certain. The location of the graphic columnar type section is given by Bradley as “***measured on Parachute Creek, Tps. 5 and 6 S., R. 96 W.***" Bradley $(1931$, p. 10) stated that paper shale is the characteristic feature of the Garden Gulch, constituting $20-40$ percent of the member. He also stated, "The greater part of the Garden Gulch Member consists of flaky shale and more thickly laminated marlstone, some of which is shaly." The member also includes a few algal and oolitic beds and a few thin beds of sandstone and siltstone. Some of the shale and marlstone beds include oil shale. Bradley apparently established the contact with the overlying Parachute Creek Member at the base of the lowest group of conspicuous oil-shale beds of the Parachute Creek Member.

The Garden Gulch throughout the Piceance Creek basin is generally defined on the dominant lithology of fissile to papery or thin-bedded dark clay shale. In the report area it is in large part laterally equivalent to the Anvil Points and Douglas Creek Members, which mostly replace it to the west in the valley of Clear Creek and its tributaries. The Garden Gulch lacks the indicators of nearshore lacustrine deposits that characterize the laterally equivalent parts of the Douglas Creek Member such as numerous algal beds, abundant siltstone and sandstone beds, nonbedded claystone and mudstone, and a relatively low content of organic material. The shale of the Garden Gulch was deposited in relatively deeper, quieter water of Lake Uinta during an early freshwater phase.

The lower and upper contacts of the Garden Gulch in the valley of Parachute Creek are essentially those defined by Bradley. The lower contact is drawn at the top of the highest conspicuous sandstone bed of the Anvil Points Member. The upper contact is described above. The Garden Gulch Member in this area is gray- to grayish-brownweathering variably silty dolomitic claystone, clay shale, dolomitic shale, shaly marlstone, and marlstone. The Garden Gulch also contains several beds of brownweathering siltstone and sandstone, a few beds of fissile oil shale mostly in the upper part, and a few thin algal limestone beds. The Kimball Mountain Tuff Bed (Johnson, 1984 , p. 16-18) lies about $65 \mathrm{ft}(20 \mathrm{~m})$ above the base of the member near the mouth of Garden Gulch. In the valley of 
Parachute Creek the Garden Gulch is mostly nonresistant and forms a smooth slope and is about 680-730 $\mathrm{ft}$ (207-223 m) thick.

In the drainage of Clear Creek and its tributaries in the southwestern part of the report area, rocks laterally equivalent to the Garden Gulch are mostly nearshore lacustrine and are included in the Douglas Creek Member. The changes in lithology that characterize the relations between these two members occur between Parachute Creek in the east and Clear Creek in the west and evidently occur gradually in the subsurface across this area. Conn Creek, a minor tributary of Roan Creek between Parachute Creek and Clear Creek in the southwestern part of the report area, contains outcrops of this part of the section. On the geologic map of the Mount Blaine quadrangle (Hail, 1978) the unit was assigned to the Douglas Creek Member, whereas on the geologic map of the adjoining Circle Dot Gulch quadrangle (Hail, 1982) the unit was assigned to the Garden Gulch Member. This latter usage was followed on the compilation of the 1:50,000-scale geologic map of the central Roan Plateau (Hail and others, 1989) and in this report. The arbitrary boundary between the Garden Gulch and Douglas Creek Members is placed in the subsurface between Conn Creek and Clear Creek. A lower part of the Garden Gulch extends into the Clear Creek area below the Douglas Creek Member. This lower part is mostly dark-gray to brown kerogen-rich fissile clay shale, with some siltstone, dolomitic shale and silty claystone. It also contains several thin; rich oil-shale beds. The Garden Gulch is mostly nonresistant and poorly exposed in the Clear Creek area and is about $180-220 \mathrm{ft}(55-67 \mathrm{~m})$ thick. Figure 3 shows the uppermost part of the Garden Gulch Member in the valley of Clear Creek.

\section{Douglas Creek Member}

The Douglas Creek Member of the Green River Formation crops out on the lowermost hillside slopes in the drainage of Clear Creek and its tributaries in the southwestem part of the report area. As explained above, it is mostly the westward lateral equivalent of the Garden Gulch Member of the Parachute Creek valley. The member was named and described by Bradley (1931, p. 9-10, pl. 8). The type section was measured in the Douglas Creek area at the southwestern margin of the Piceance Creek basin. Johnson (1984, p. 3-11) revised the Douglas Creek Member to exclude a tongue of the Wasatch Formation in the lower part and defined the underlying unit as the Cow Ridge Member of the Green River Formation. The Wasatch tongue crops out in the report area, and the Cow Ridge Member is present in the subsurface. The unit described by Bradley (1931, pl. 7) as Douglas Creek in the valley of Parachute Creek is, as previously noted, here designated as Anvil Points Member.

In its outcrop area along Clear Creek, the Douglas Creek Member is mostly gray, brownish-gray, and greenish- gray variably dolomitic and silty claystone, shale, and marlstone. It also contains several beds of locally ostracodal sandstone and siltstone and minor thin beds of oil shale. A few beds of algal limestone are present in the upper part. The number of algal limestone beds in the upper part of the member increases westward and southwestward from the report area into the Desert Gulch and The Saddle quadrangles (Johnson 1977a, 1981a), which is more characteristic of the member elsewhere in the Piceance Creek basin. Carbonate content generally increases from south to north and northeast in the upper part of the member. The member also contains a few very thin beds of analcimized tuff. Throughout most of the outcrop area, the upper contact of the member is drawn at the top of a conspicuous brown-weathering cliff of silty dolomitic claystone above which lie marlstone and oil shale of the Parachute Creek Member. Below the upper cliff, the Douglas Creek Member is generally nonresistant and forms slopes.

Rocks of the Douglas Creek Member represent shallow nearshore lacustrine deposits not subject to the abundant influx of coarser clastics, such as characterize the Anvil Points Member, and grade gradually eastward into the deeper freshwater strata of the Garden Gulch Member.

Figure 3 includes a detailed section of the Douglas Creek Member measured along Clear Creek near the mouth of Deer Park Gulch. The member is about $640-720 \mathrm{ft}$ (195-220 m) thick.

\section{Parachute Creek Member}

The Parachute Creek Member is the youngest member of the Green River Formation and is present throughout most of the Piceance Creek basin. It contains most of the potentially valuable oil shale of the Green River. The Parachute Creek Member consists mostly of dolomitic marlstone much of which is oil shale. The member conformably overlies the Garden Gulch or Douglas Creek Members and is complexly intertongued with the overlying Uinta Formation.

The member was named by Bradley (1931, p. 11-19, pl. 7) for exposures along Parachute Creek in and near the report area. The actual location of Bradley's measured type section of the Parachute Creek Member, like that of the type Garden Gulch, is not clear. Bradley defined the member chiefly on its content of oil-shale beds. In his type section, he placed the base of the Parachute Creek at the base of the lowermost group of oil-shale beds and the top of the member at the top of the uppermost group of oil-shale beds. Subsequent studies have shown that visual estimation of oil content of outcropping beds is not a reliable basis for stratigraphic correlation. The use of drill-hole logs, especially Fischer assay logs, has demonstrated that rocks low in oil-shale values and possibly perceived to be barren in outcrop exposures can be correlated with considerable precision with high-yield oil shale elsewhere. For example, 

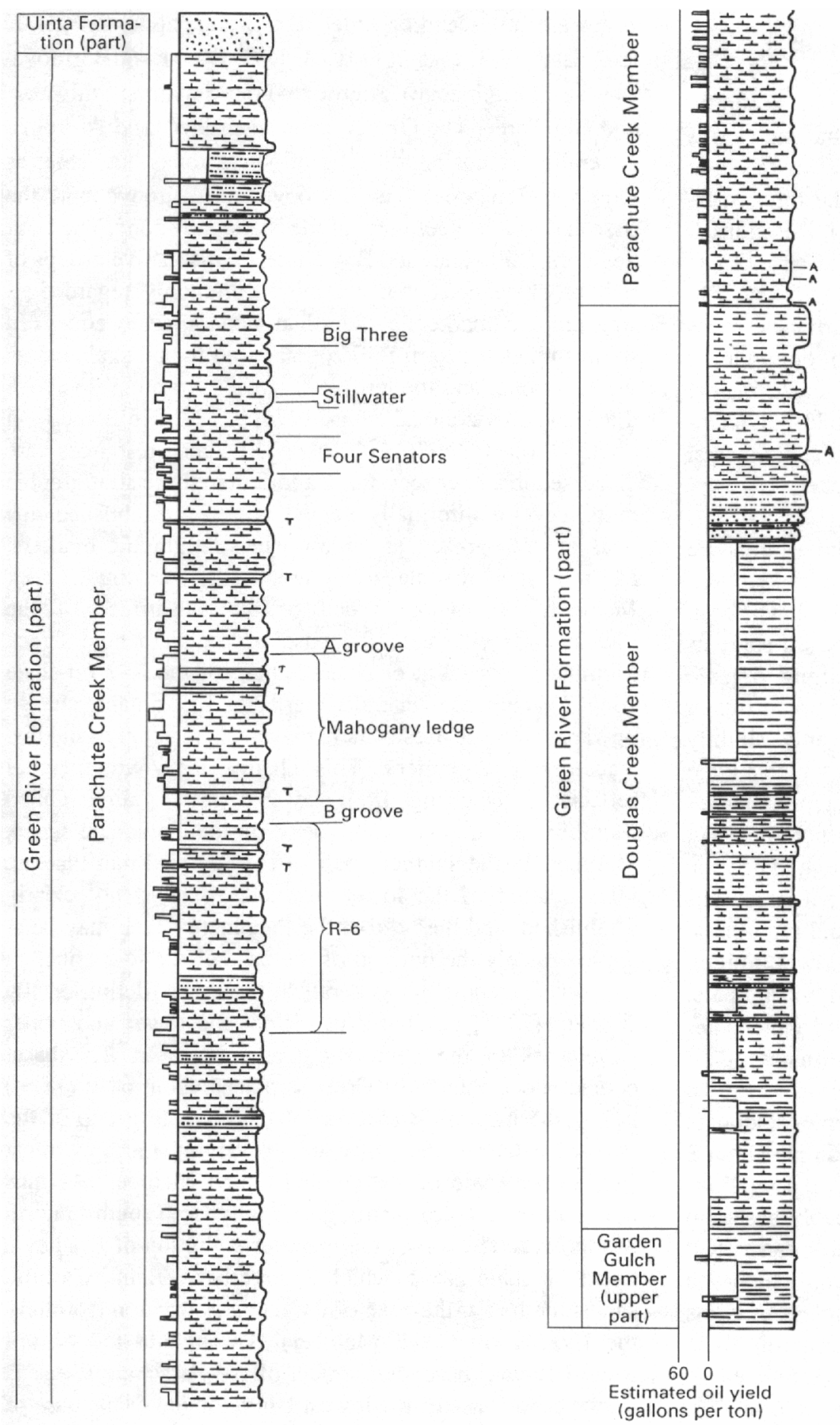

EXPLANATION

Marlstone

Dolomitic shale

Claystone, varlably dolomitic and variably silty

$\underline{\overline{E-}}$ Clay shale

$E=0.0$

Sandstone

$\square$ Poorly exposed interval

T Tuff bed

A Algal limestone bed

METERS FEET

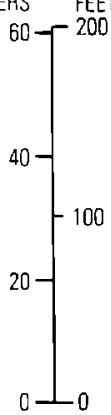

Figure 3. Measured section of part of the Green River Formation, near the mouth of Deer Park Gulch. Garden Gulch and Douglas Creek Members were measured in the S1/2 sec. 10, and NW1/4 sec. 15, T. 6 S., R. 98 W.; Parachute Creek Member and Uinta Formation are adapted from Waldron and others (1951, sheet 1, column 6), measured in the SE $1 / 4$ of sec. 10 and $\mathrm{NW}^{1 / 4} / 4$ of sec. 11, T. 6 S., R. $98 \mathrm{~W}$.

Cashion and Donnell $(1974$, p. 4-5), in their revision of correlations and nomenclature for the upper part of the Green River Formation, showed by means of assay logs that the upper part of the type Parachute Creek is laterally equivalent to part of the type Evacuation Creek Member (now abandoned) of the Green River Formation. Recent mapping and related stratigraphic studies have based stratigraphic correlations of the Parachute Creek Member on lithologic studies and oil-shale assay and other drill-hole logs. 
Lithologic Terms: Marlstone and Oil Shale

The lithologic terminology used by Bradley (1931, p. $6-8,22)$ for rocks of the Green River Formation generally has been followed in subsequent studies, but the terms marlstone and oil shale have been used with little consistency. Bradley (1931, p. 7) adopted the term marlstone based on the European terminology of $\mathrm{H}$. Rosenbusch to refer to a hard variety of marl consisting of an intimate mixture of calcite, occasionally of dolomite, and clay. The term marlstone has been widely applied to carbonate rocks of the Parachute Creek Member in which dolomite is generally more abundant than calcite. In much of the marlstone of the Parachute Creek, quartz, feldspar, analcime, and saline minerals are commonly major constituents; clay (illite) content is low (Brobst and Tucker, 1973, p. 28-34).

The term oil shale has been used as both a lithologic term and as an economic resource term, and both kerogenrich marlstone and kerogen-rich clay shale have been termed oil shale. Bradley $(1931$, p. 7$)$ defined oil shale as “***a fine-grained sedimentary rock containing organic matter which was derived chiefly from aquatic organisms or waxy spores and pollen grains, which is only slightly soluble in ordinary petroleum solvents, and of which a large proportion is distillable into artificial petroleum." Bradley pointed out that most rich oil-shale beds are not shale but rather are more or less magnesian marlstones rich in organic matter. He set no lower limit on oil yield but set 10 gallons per ton as the boundary between low-grade and high-grade oil shale. Many workers, however, have set a lower limit on oil yield below which the rock is not termed an oil shale. This limit varies widely, generally from 3 to 15 gallons per ton (12-60 liters per metric ton). Visual estimates of oil yield in the field are based primarily on the pervasive brown color imparted by the organic material. Such color seldom is seen in outcropping marlstone containing less than about 3 gallons per ton. The higher values of from 10 to 15 gallons per ton (40-60 liters per metric ton) are probably based on a concept of possible economic value. Assays can detect very low oil-yield values, approaching zero, which are useful in stratigraphic correlation but meaningless in terms of economic potential. In this report, the term oil shale refers to marlstone or clay shale having an estimated or assayed oil yield of no less than 3 gallons per ton.

\section{Oil-Shale Zones and Key Beds}

In most U.S. Geological Survey reports since about 1970 (Donnell and Blair, 1970) dealing with oil-shale resources of the Green River Formation in the Piceance Creek basin, the oil-shale sequence is divided into informally named or numbered rich and lean zones and certain widely recognized key marker beds, mostly above the Mahogany oil-shale zone. Numbered rich oil-shale zones are designated $\mathrm{R}$; lean zones are designated $\mathrm{L}$. The zones are (in ascending order) the Orange zone, $\mathrm{R}-1, \mathrm{~L}-1$, $\mathrm{R}-2, \mathrm{~L}-2, \mathrm{R}-3, \mathrm{~L}-3, \mathrm{R}-4, \mathrm{~L}-4, \mathrm{R}-5, \mathrm{~L}-5, \mathrm{R}-6, \mathrm{~B}$ groove, Mahogany (rich zone), A groove, Four Senators, Stillwater, and Big Three. The Orange zone, $\mathrm{B}$ groove, and $\mathrm{A}$ groove generally are not regarded as oil-shale zones but rather as mostly barren zones. The $B$ groove and A groove mark the base and top, respectively, of the Mahogany zone. The Four Senators, Stillwater, and Big Three are distinctive groups of rich oil-shale beds that are more commonly regarded as stratigraphic markers rather than rich oil-shale zones. In some studies the term $R-0$ zone is used for oil shale below the $R-1$ zone, and the term R-8 is used for oil shale above the Mahogany zone (Ziemba, 1974, p. 127; Rio Blanco Oil Shale Project, 1976, p. 29). Oil-shale resources are discussed in a later section. In addition to these stratigraphic units, several informally named but well-established tuff beds are recognized as widespread stratigraphic markers. Most of the oil-shale zones are in the Parachute Creek Member. Throughout much of the subsurface of the Piceance Creek basin, the base of the Parachute Creek Member is placed at or near the base of the R-2 oil-shale zone. This horizon generally marks the first notable change upward from a freshwater to an increasingly alkaline lacustrine environment. This change in environment is reflected in the change from clay shale of the Garden Gulch Member to carbonate-rich rocks of the Parachute Creek Member. In the southern part of the central Roan Plateau, identification of the lower oil-shale zones is not clearly established, and the base of the Parachute Creek may be at approximately the horizon of the base of the $\mathrm{R}-3$ zone.

This report in general follows the definition by Bradley (1931, p. 11-14, pl. 7) for the lower and upper boundaries of the Parachute Creek Member. The basal contact along Parachute Creek is placed about $60 \mathrm{ft}(18 \mathrm{~m})$ below the base of Bradley's lower oil-shale group at the base of a barren marlstone unit overlying the uppermost fissile clay shale of the Garden Gulch Member. As thus defined the base drops stratigraphically from south to north in this area. The top of the member is the top of Bradley's upper oil-shale group, which is directly overlain by a limy sandstone bed at the base of the Uinta Formation (formerly the Evacuation Creek Member). Throughout the central Roan Plateau, the upper contact of the Parachute Creek is drawn at the base of the lowest Uinta tongue or the base of the main body of the Uinta. As thus drawn, the upper contact of the Parachute Creek rises stratigraphically from north to south because of the southward pinchout of several successive Uinta tongues. The Green River and Uinta Formations are complexly intertongued through a vertical stratigraphic range of as much as $1,000 \mathrm{ft}(305 \mathrm{~m})$. Tongues of the Green River are marlstones, most of which merge laterally into rocks of the Parachute Creek Member, but, owing to constraints of stratigraphic nomenclature in which members and tongues have equal status, the marlstone bodies are designated tongues of the Green River Formation 
rather than tongues of the Parachute Creek Member. The intertonguing Green River and Uinta units are described elsewhere. In the drainage of Clear Creek in the southwestern part of the area where the Parachute Creek Member lies on the Douglas Creek Member, the basal contact of the Parachute Creek is drawn at the base of the lowermost oil-shale beds within a thick marlstone sequence that overlies non-oil-shale-bearing dolomitic shale beds of the underlying Douglas Creek. Figure 3 shows a section of the Parachute Creek Member measured along Clear Creek near the mouth of Deer Park Gulch in the southwestern part of the report area. In addition to the measured type section (Bradley, 1931, pl. 7), several detailed measured sections in and near the report area are shown by Waldron and others (1951, fig. 1).

The lithology of the member almost everywhere in the report area is dominantly dolomitic carbonate marlstone, much of which is oil shale. The marlstone weathers light gray to light brown. The member also contains some silty marlstone and marly siltstone and a few beds of siltstone and sandstone. Very thin beds of analcimized tuff are numerous throughout the member. In the lower part of the member are a few algal beds and some fissile shale and dolomitic claystone. The marlstones of the Parachute Creek Member are dense, hard, resistant rocks and generally form steep cliffs and resistant ledges. The oil-shale marlstones are medium to dark brown on fresh surfaces and most weather light gray. Rich oil shale, exceeding 30 gallons per ton, weathers to a distinctive bluish gray. Barren marlstone is gray to light grayish brown and also weathers light gray.

The Parachute Creek is about $1,000-1,600 \mathrm{ft}$ $(305-490 \mathrm{~m})$ thick. It is apparently thickest in the subsurface in the northeastern part of the area.

\section{Uinta Formation and Tongues of the Green River Formation}

The Uinta Formation of late Eocene age is a heterogeneous mass of clastic rocks, mostly sandstone, siltstone, and variably silty to sandy marlstone and lesser mudstone and shale and minor conglomerate and other rock types. These rocks comprise the thick, generally southwardprograding, fluvial-deltaic sequence that ultimately filled Lake Uinta. Much of the Uinta Formation consists of southward-thinning wedges of clastic rocks that interfinger with northward-thinning tongues of marlstone of the Green River Formation. Deposition was at times localized, shifting, or intermittent and was interrupted by episodes of open-water lacustrine deposition during which marlstone tongues of the Green River Formation were deposited. This depositional pattern resulted in complex intertonguing between the Green River and Uinta Formations. The southward-prograding deltaic nature of the Uinta Formation is described by Johnson (1981b, p. 56-58). In general, successively younger tongues of the Uinta extend farther south beyond the pinchout edge of older tongues. This pattern of intertonguing is shown by Trudell and others (1970, fig. 4), based on subsurface studies, and by Duncan and others (1974, fig. 4), O'Sullivan (1975, fig. 2), Hail (1977b, fig. 2), and Johnson (1981b, fig. 1), based on detailed mapping and subsurface correlations. Many of the detailed mapping and subsurface studies throughout the Piceance Creek basin show that most of the marlstone tongues of the Green River Formation merge generally southward with other Green River tongues or with the main body of the Parachute Creek Member. Not all marlstone tongues of the Green River have been mapped separately in the report area or elsewhere in the Piceance Creek basin. Generally only the more widespread, conspicuous, or otherwise selected units were mapped. Marlstone units not mapped separately are included in the Uinta Formation. The intertonguing sequence is mostly made up of the Uinta Formation, and the marlstone tongues of the Green River are relatively thin. Figures 4-7 show the correlations of mapped Green River and Uinta tongues among the four $71 / 2$-minute quadrangles of the report area. In the 1:50,000scale geologic map of the Roan Plateau area (Hail and others, 1989), the intertonguing sequence is divided into two groups because of the map scale. Individual tongues are not shown. The lower group is designated map unit Tugl, the upper map unit Tugu. The contact between the groups is generally the top of the Stewart Gulch Tongue of the Green River Formation. The description of individual tongues below is based on this division. The Uinta-Green River

\begin{tabular}{|c|c|}
$\begin{array}{c}\text { BULL FORK } \\
\text { QUADRANGLE } \\
\text { (MF-830) }\end{array}$ & $\begin{array}{c}\text { CUTOFF GULCH } \\
\text { OUADRANGLE } \\
\text { (MF-691) }\end{array}$ \\
\hline Tue & Tud \\
\hline Tgbf & Tgb \\
\hline Tud & Tuc \\
\hline Tgb & Tgs \\
\hline Tuc & Tub \\
\hline Tgs & Tgc \\
\hline Tub & Tua \\
\hline Tgc & Tgp \\
\hline Tua & \\
\hline Tgp & \\
\hline
\end{tabular}

Figure 4. Correlation of mapped units in the intertongued sequence of the Green River and Uinta Formations between the Bull Fork (Hail, 1977a) and the Cutoff Gulch (Hail, 1975) quadrangles. All units shown are tongues of the Green River (Tg) or Uinta (Tu) Formations except the Parachute Creek Member of the Green River Formation (Tgp) and the uppermost Uinta unit in each column. Uinta units are shaded. Formally named tongues of the Green River Formation are Stewart Gulch Tongue (Tgs) and Coughs Creek Tongue (Tgc). Symbols: Tue, Uinta unit E; Tgbf, marker bed at Bull Fork; Tud, Uinta unit D; Tgb, marlstone at Barnes Ridge; Tuc, Uinta unit C; Tgs, Stewart Gulch Tongue; Tub, Uinta unit B; Tgc, Coughs Creek Tongue; Tua, Uinta unit A; Tgp, Parachute Creek Member. 


\begin{tabular}{|c|c|c|c|}
\hline \multicolumn{2}{|c|}{$\begin{array}{c}\text { MOUNT BLAINE } \\
\text { QUADRANGLE } \\
\text { Eastern part } \\
\text { (MF-984) }\end{array}$} & \multicolumn{2}{|c|}{$\begin{array}{l}\text { CIRCLE DOT GULCH } \\
\text { QUADRANGLE } \\
\text { (MF-1293) }\end{array}$} \\
\hline \multicolumn{2}{|c|}{ Tud } & \multicolumn{2}{|c|}{ Tud } \\
\hline \multicolumn{2}{|c|}{ Tgs! } & \multicolumn{2}{|c|}{ Tgj } \\
\hline \multicolumn{2}{|c|}{ Tuc } & \multicolumn{2}{|c|}{ Tuc } \\
\hline & Tgs & Tgs & \\
\hline \multirow[t]{4}{*}{ Tgp } & Tub & Tub & Tgp \\
\hline & Tgc & Tgc & \\
\hline & Tua & Tua & \\
\hline & Tgp & Tgp & \\
\hline
\end{tabular}

Figure 5. Correlation of mapped units in the intertongued sequence of the Green River and Uinta Formations between the Mount Blaine (Hail, 1978) and the Circle Dot Gulch (Hail, 1982) quadrangles. All units shown are tongues of the Green River $(\mathrm{Tg})$ or Uinta $(\mathrm{Tu})$ Formations except the Parachute Creek Member of the Green River Formation (Tgp) and the uppermost Uinta unit in each column. Uinta units are shaded. Formally named tongues of the Green River Formation are Stewart Gulch Tongue (Tgs) and Coughs Creek Tongue (Tgc). Symbols: Tud, Uinta unit D; Tgp, Parachute Creek Member; Tgsl, marlstone at Sleepy Ridge; Tgj, marlstone at Jackrabbit Ridge; Tuc, Uinta unit C; Tgs, Stewart Gulch Tongue; Tub, Uinta unit B; Tgc. Coughs Creek Tongue; Tua, Uinta unit A. Vertical dashed lines are lateral boundaries between map units.

intertonguing sequence and the Uinta Formation form by far the largest area of exposed Tertiary rocks in the Piceance Creek basin and most of the surface rocks in the report area. Mapping of the thin marlstone tongues of the Green River Formation throughout the basin has provided a basis for recognizing and subdividing the complex stratigraphy of the sequence and for deducing its depositional history.

The Uinta Formation, most of which intertongues with mapped tongues of the Green River Formation, includes a wide range of rock types. Brown-weathering sandstone and siltstone make up the bulk of the formation, but variably silty gray-weathering marlstone, mudstone, or claystone is also abundant. Conglomerate is present locally. Thin beds of Green River-type light-gray marlstone are also included in some tongues. Altered tuffaceous material is abundant and forms the dominant mineral constituent in many beds. The mapped tongues are highly variable in thickness. Several terminate laterally in or near the report area either as a result of pinchout or abrupt facies change. Basal contacts of the tongues of Uinta are gradational to sharply disconformable. They commonly are sharp and show no evident structural discordance or are gradational across a narrow stratigraphic interval from white marlstone of the underlying tongues of the Green River Formation to brown-weathering siltstone or sandstone of a tongue of the Uinta. Where the contacts appear to be disconformable, the underlying beds may locally be scoured. In many places, the bases of broken sandstone masses are downwarped or slumped into the underlying marlstone beds. This slumping

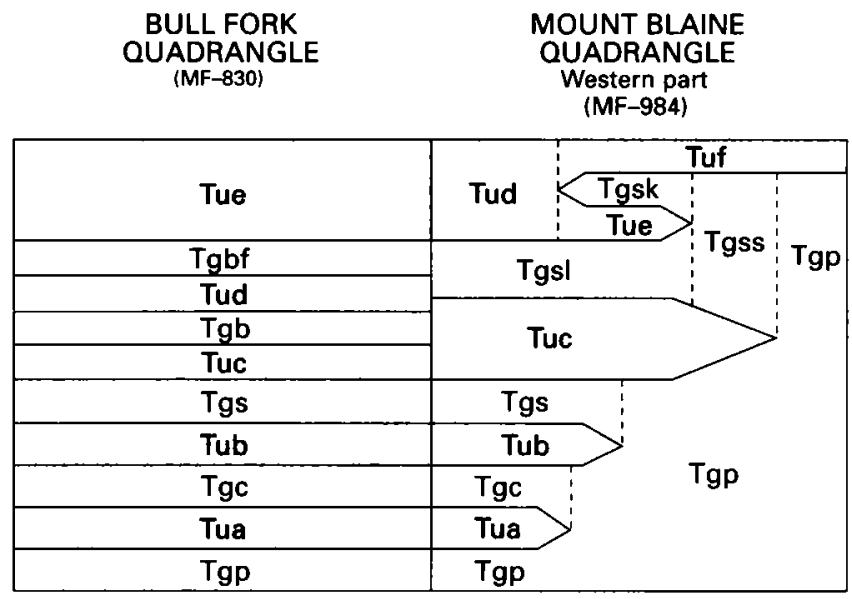

Figure 6. Correlation of mapped units in the intertongued sequence of the Green River and Uinta Formations between the Bull Fork (Hail, 1977a) and the western part of the Mount Blaine quadrangles (Hail, 1978). All units shown are tongues of the Green River $(\mathrm{Tg})$ or Uinta $(\mathrm{Tu})$ Formations except the Parachute Creek Member of the Green River Formation (Tgp) and the uppermost Uinta unit in each column. Uinta units are shaded. Formally named tongues of the Green River are Stewart Gulch Tongue (Tgs) and Coughs Creek Tongue (Tgc). Symbols: Tue, Uinta unit E; Tud, Uinta unit D; Tuf, Uinta unit F; Tgsk, marlstone at Skinner Ridge; Tgss, marlstone at Skinner Ridge and marlstone at Sleepy Ridge, undivided; Tgp, Parachute Creek Member; Tgbf, marker bed at Bull Fork; Tgsl, marlstone at Sleepy Ridge; Tuc, Uinta unit $C$; Tgb, marlstone at Barnes Ridge; Tgs, Stewart Gulch Tongue; Tub, Uinta unit B; Tgc, Coughs Creek Tongue; Tua, Uinta unit A. Vertical dashed lines are lateral boundaries between map units.

was penecontemporaneous with deposition and occurred after some degree of consolidation of the sandstone that was deposited on the underlying soft nonresistant or poorly indurated marly sediments. The underlying marlstones also commonly show considerable distortion including differential compaction, plastic flow, and minor local faulting.

Most of the Uinta Formation is marly or argillacaeous siltstone or very fine to fine grained sandstone, but coarsegrained sandstone and conglomeratic sandstone beds are present locally. The sediments were mostly deposited in a lacustrine delta-front environment. Many of the tongues, however, locally contain channel-form sandstones, some of which may be fluvial in origin. Where firmly cemented, the siltstones and sandstones form cliffs or benches.

In this report the intertongued Green River Formation-Uinta Formation sequence is divided into a lower part and an upper part. The Uinta Formation above the upper part is described separately. This arrangement follows the usage of the Roan Plateau 1:50,000-scale map (Hail and others, 1989), which covers the report area. On that map the lower part is designated map unit Tugl, the upper part Tugu, and higher beds simply as map unit Tu. The contact between the lower and upper parts is generally the top of the 


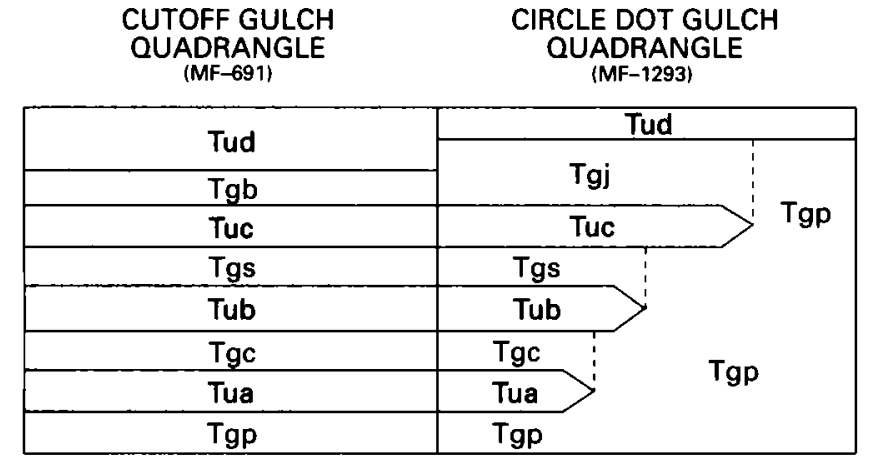

Figure 7. Correlation of mapped units in the intertongued sequence of Green River and Uinta Formations between the Cutoff Gulch (Hail, 1975) and the Circle Dot Gulch quadrangles, (Hail, 1982). All units shown are tongues of the Green River $(\mathrm{Tg})$ or Uinta (Tu) Formations except Tgp (Parachute Creek Member of the Green River Formation) and the uppermost Uinta unit in each column. Uinta units are shaded. Formally named tongues of the Green River Formation are Stewart Gulch Tongue (Tgs) and Coughs Creek Tongue (Tgc). Explanation of symbols: Tud, Uinta unit D; Tgj, marlstone at Jackrabbit Ridge; Tgp, Parachute Creek Member; Tgb, marlstone at Barnes Ridge; Tuc, Uinta unit $C$; Tgs, Stewart Gulch Tongue; Tub, Uinta unit B; Tgc, Coughs Creek Tongue; Tua, Uinta unit A. Vertical dashed lines are lateral boundaries between map units.

Stewart Gulch Tongue of the Green River Formation. Individual tongues described below are shown on the four constituent 71/2-minute quadrangle maps. Plates 1 and 2 show correlation of parts of the intertongued sequence, as well as oil-shale zones in Fischer assay histograms of selected oil-shale test drill holes.

\section{Lower Part of the Intertongued Sequence}

The lower part of the Green River-Uinta intertongued sequence includes two tongues of the Green River Formation and two tongues of the Uinta Formation (see figs. 4-7). All these units are shown on all four of the constituent 71/2-minute geologic maps. These units are (in ascending order) Uinta Formation unit A (map unit Tua), Coughs Creek Tongue of the Green River Formation, (map unit Tgc), Uinta Formation unit B (map unit Tub), and Stewart Gulch Tongue of the Green River Formation (map unit Tgs).

\section{Uinta Unit A}

The stratigraphically lowest tongue of the lower part, Uinta unit A (map unit Tua), is present throughout the Bull Fork and Cutoff Gulch quadrangles and pinches out or reaches its limit of mappability roughly along a southeasterly trending line in the northern part of the Mount Blaine and Circle Dot Gulch quadrangles.

The unit consists mostly of brown-weathering siltstone and lesser very fine grained sandstone. The siltstone beds are variably marly and locally contain abundant carbonized plant fragments. The unit also contains some platy marlstone in its lower part along East and West Willow Creeks in the northwestern part of the area and near the southeastern part of its outcrop area. It is mostly a nonresistant slope-forming unit, but some ledges are present locally. Its maximum thickness is not known. Exposed beds are as much as $250 \mathrm{ft}(76 \mathrm{~m})$ thick along the Middle Fork of Stewart Gulch near the northern boundary of the area. The base is not exposed here, however, and the unit may be considerably thicker.

\section{Coughs Creek Tongue of the Green River Formation}

The lowermost tongue of the Green River Formation in the report area is the Coughs Creek Tongue (map unit Tgc). The Coughs Creek Tongue is present throughout the Bull Fork and Cutoff Gulch quadrangles and extends south into the Mount Blaine and Circle Dot Gulch quadrangles. The Coughs Creek is present throughout a large area of the southern Piceance Creek basin (O'Sullivan, 1975). In the report area the tongue terminates along the southeastwardtrending pinchout line of the underlying Uinta tongue (map unit Tua) described above in the northern part of the Mount Blaine and Circle Dot Gulch quadrangle, where the Coughs Creek Tongue merges with the Parachute Creek Member of the Green River Formation.

The Coughs Creek is mostly light-gray-weathering variably silty marlstone including oil shale. The unit also contains siltstone, especially in the northern part of the report area, and a persistent bed of siltstone is present in the middle part of the unit in the northeastern part of the area. The unit commonly includes two or three lean oil-shale beds separated by siltstone beds. The oil shale becomes richer southward. Oil yields are estimated generally at about 5-20 gallons per ton (20-80 liters per metric ton). The Coughs Creek can be identified in oil-shale histograms of drill holes beyond the merger line of the tongue with the Parachute Creek Member (pls. 1 and 2). A few very thin blueweathering rich oil-shale beds are present locally. The Coughs Creek is a relatively nonresistant slope-forming unit in the northern part of the area, but the unit forms resistant steep-faced cliffs in the southeastern part of its outcrop area owing to increased oil-shale contents. The Coughs Creek is about $20-45 \mathrm{ft}(6-14 \mathrm{~m})$ thick.

\section{Uinta Unit B}

Overlying the Coughs Creek Tongue is Uinta unit B (map unit Tub), a tongue of the Uinta Formation. It is present in the Bull Fork and Circle Dot Gulch quadrangles and pinches out or reaches its limit of mappability along a southeast- and east-trending line in the northem to central parts of the Mount Blaine and Circle Dot Gulch quadrangles.

The unit consists of brown-weathering sandstone and siltstone, silty marlstone, and marlstone including some oil 
shale. In the northwestern part of the area, it also includes some greenish-gray silty shale, sparse clay-pebble conglomerate, and tuff. The unit is an abruptly southwardthinning wedge (pl. 1) whose sediments generally become finer grained as the unit thins and approaches its pinchout line. Sandstone beds are more abundant in the northem part of the area where the unit is thickest. Grain size of most of the sandstone beds is fine to medium. Some of the sandstone beds are in channels cut into underlying beds of the Coughs Creek Member and into higher beds within the unit. Paleoslump blocks of sandstone masses are present locally in the northern part of the area where sandstones are more abundant. The unit contains considerable silty marlstone along upper Hunter Creek in the northwestern part of the area and a persistent marlstone bed in the same area. Brown-weathering siltstone beds predominate as the unit thins southward. Most of these contain varying amounts of carbonized plant fragments and are more marly southward. A bed of lean oil shale as much as $20 \mathrm{ft}(6 \mathrm{~m})$ thick is present in the unit (pl. 1, column 3) in the upper drainage area of Parachute Creek in the Circle Dot Gulch quadrangle. The oil content of the bed is estimated at 10-12 gallons per ton (40-48 liters per metric ton). In the northern part of the report area, where sandstone beds predominate, the more resistant beds form ledges and prominent cliffs. Southward, however, where siltstone predominates, these beds are mostly nonresistant and form slopes. The maximum thickness of the unit where it is thickest in the northern part of the area is about $400-450 \mathrm{ft}(120-140 \mathrm{~m})$. The unit is only about $40 \mathrm{ft}(12 \mathrm{~m})$ thick along Light Gulch (pl. 1, column 3$)$, about $2 \mathrm{mi}(3 \mathrm{~km})$ north of the pinchout line.

\section{Stewart Gulch Tongue of the Green River Formation}

The uppermost unit of the lower part of the intertongued Green River-Uinta sequence is the Stewart Gulch Tongue of the Green River Formation. The Stewart Gulch Tongue is present throughout the Bull Fork and Cutoff Gulch quadrangles and extends southward into the Mount Blaine and Circle Dot Gulch quadrangles. The Stewart Gulch Tongue is present throughout a large area of the south-central Piceance Creek basin (Hail, 1977b). The type locality is along the Middle Fork of Stewart Gulch in the NW $1 / 4$ sec. 3, T. 4 S., R. 96 W., in the northeastern part of the report area. Within the report area, the tongue terminates along an east- and southeast-trending pinchout line of the underlying Uinta tongue (map unit Tub) described above in the northern and central parts of the Mount Blaine and Circle Dot Gulch quadrangles where the Stewart Gulch merges with the Parachute Creek Member of the Green River Formation.

Throughout much of its outcrop area, the Stewart Gulch is dominantly marlstone. In the northern part of the report area, including the type locality, the tongue also includes beds of light-brown fine- to medium-grained sandstone, greenish-gray marly siltstone containing sparse carbonized plant fragments, and minor dolomitic shale. The marlstone is dolomitic, variably silty, and light gray to light brown and weathers light gray. It is laminar, even bedded to nonbedded. In the central parts of the Bull Fork and Cutoff Gulch quadrangles and southward into the Mount Blaine and Circle Dot Gulch quadrangles, the marlstones of the Stewart Gulch grade to increasingly rich oil shales, so that the unit is dominantly oil shale where it merges into the Parachute Creek Member. Individual oil-shale beds of the Stewart Gulch Tongue can be identified in oil-shale Fischer assay histograms of drill holes beyond the merger line of the tongue with the Parachute Creek Member (pls. 1 and 2). Locally in the northem part of the report area, the Stewart Gulch Tongue is nonresistant and forms slopes, but in most places the unit forms a single resistant steep-faced conspicuous cliff, particularly on well-exposed canyon walls in the southern part of its outcrop area. The Stewart Gulch Tongue is thinnest near the northern boundary of the report area, probably no more than $5 \mathrm{ft}(1.5 \mathrm{~m})$ thick in places. It probably pinches out within $2-3 \mathrm{mi}(3-5 \mathrm{~km})$ north of the northern boundary of the report area. It is thickest, about $70 \mathrm{ft}(21 \mathrm{~m})$, in the northeastern part of the Mount Blaine quadrangle.

\section{Upper Part of the Intertongued Sequence}

The upper part of the Green River-Uinta intertongued sequence includes six tongues of the Green River Formation and three tongues of the Uinta Formation (figs. 4-7). These units are shown on the constituent $71 / 2$-minute maps and are (in ascending order) Uinta Formation unit C (map unit Tuc), marlstone unit of the Green River at Bames Ridge (map unit Tgb), Uinta unit D (map unit Tud of the Bull Fork quadrangle), marker bed of the Green River at Bull Fork (map unit Tgbf), marlstone unit of the Green River at Jackrabbit Ridge (map unit Tgj), marlstone unit of the Green River at Sleepy Ridge (map unit Tgsl), Uinta Formation unit $\mathrm{E}$ (map unit Tue of the Mount Blaine quadrangle), marlstone unit of the Green River at Skinner Ridge (map unit Tgsk), and marlstone unit at Sleepy Ridge and marlstone unit at Skinner Ridge undivided (map unit Tgss). Higher map units of the Uinta shown on figures 4-7 are discussed separately elsewhere.

\section{Uinta Unit C}

The stratigraphically lowest tongue of the upper part, Uinta unit C (map unit Tuc), is present throughout the Bull Fork and Cutoff Gulch quadrangles and pinches out or reaches its limit of mappability along an east- and northeasttrending line in the southern part of the Mount Blaine quandrangle and southwest to east-central part of the Circle Dot Gulch quadrangle. The position of the upper boundary of Uinta unit $\mathrm{C}$ at various stratigraphic positions was established by the mapping of certain overlying tongues of 
the Green River Formation of limited extent, some of which were not carried as map units across adjacent quadrangle boundaries owing to pinching out, facies changes, or other factors (see figs. 5 and 6). The mapping of these Green River tongues is described below.

Uinta unit $\mathrm{C}$ consists of brown-weathering siltstone, sandstone, and a few beds of marlstone. Minor beds of shale and claystone are present locally. Sandstone beds are abundant in the northeastern part of the area but become fewer and thinner and grade laterally to siltstone elsewhere as the unit thins, and siltstone is the dominant lithology. The sandstone beds are very fine to medium grained. Minor coarse-grained sandstone beds are present locally. The thicker sandstone beds are generally impure, containing abundant clay fragments, rock grains, biotite, and other minerals. These beds are commonly nonresistant; bedding is massive or indistinct. Some of the thinner sandstone beds are locally even bedded. The sandstones mostly lack the channel-form beds and paleoslump blocks that characterize Uinta unit B described above. The siltstone beds weather light brown, contain varying amounts of carbonized plant fragments, and generally are more marly to the south. The unit also contains thin variably silty marlstone beds. Throughout much of the Mount Blaine quadrangle, the unit includes marlstone equivalent to the marlstone at Barnes Ridge, which is mapped separately to the north in the Bull Fork quadrangle (fig. 6, map unit Tgb). The Barnes Ridge equivalent is barren marlstone in the northern part of the Mount Blaine quadrangle but grades to increasingly rich oil shale toward the southwest in the quadrangle. The unit contains a 53-foot-thick $(16 \mathrm{~m})$ but apparently nonpersistent bed of barren marlstone in the vicinity of West Fork Falls along the West Fork of Parachute Creek near the southern boundary of the Cutoff Gulch quadrangle (pl. 1, column 2). Some resistant sandstone and siltstone beds form ledges, mostly in the northern part of the area; elsewhere the unit is generally nonresistant and forms slopes. The maximum thickness of the unit where it is thickest in the northern part of the report area is about $360 \mathrm{ft}(110 \mathrm{~m})$. The pronounced southward thinning of the unit is shown on plate 1 .

\section{Marlstone at Barnes Ridge}

The lowermost tongue of the Green River Formation in the upper part of the intertonguing sequence is the marlstone at Barnes Ridge, informally named for exposures along Barnes Ridge in the eastern part of the Cutoff Gulch quadrangle (Hail, 1975). The unit, a thin conspicuous light-gray-weathering marlstone bed, is mapped as a separate unit throughout the northern part of the report area mapped in the Bull Fork and Cutoff Gulch quadrangles (fig. 4). It was also mapped by Johnson (1977b) in the Figure Four Spring quadrangle, adjacent on the west to the Bull Fork quadrangle. It is also present in much of the Mount Blaine quadrangle but was mapped with the underlying
Uinta unit $C$ (fig. 6). In the southeastern part of the area, near the West Fork of Parachute Creek, it merges southward with higher marlstone beds and is included with the marlstone at Jackrabbit Ridge (map unit Tgj) in the Circle Dot Gulch quadrangle (fig. 7) and in the two quadrangles adjacent on the east to the report area, the McCarthy Gulch (O'Sullivan and others, 1981) and the Forked Gulch (O'Sullivan and Hail, 1987) quadrangles.

Where mapped separately, the unit is dominantly light-gray-weathering variably silty dolomitic marlstone that is laminar even bedded to nonbedded. It locally contains thin beds of marly siltstone, very fine grained sandstone, and lean oil shale. In the Mount Blaine quadrangle, where equivalent strata are included in Uinta unit $\mathrm{C}$ (map unit Tuc), the Barnes Ridge unit grades southward to increasingly rich oil shale. The Bames Ridge unit is locally absent owing to pre-Uinta unit D erosion, as near the mouth of the Wet Fork of Parachute Creek in the southwestern corner of the Cutoff Gulch quadrangle and near upper West Willow Creek in the central part of the Bull Fork quadrangle, and the unit may thin by erosion elsewhere. The Barnes Ridge unit is mostly nonresistant and generally forms slopes. It is about 5-50 ft (1.5-15 m) thick.

\section{Uinta Unit D of the Bull Fork Quadrangle}

The next stratigraphically higher tongue of the Uinta Formation is Uinta unit D as mapped in the Bull Fork quadrangle (map unit Tud only in the Bull Fork quadrangle), which differs from Uinta unit $D$ as mapped elsewhere owing to the presence in the Bull Fork quadrangle of an overlying locally mapped tongue of the Green River Formation, the marker bed at Bull Fork (map unit Tgbf). It is for this reason arbitrarily included in the upper part of the intertonguing sequence but it is continuous with and laterally equivalent to much of the main body of the Uinta (map unit Tud) in the Cutoff Gulch quadrangle to the east (fig. 4).

Unit $\mathrm{D}$ of the Bull Fork quadrangle is a heterogeneous eastward-thinning wedge consisting mostly of brownweathering sandstone and siltstone and lesser marlstone. Where thickest, in the southwestern part of the Bull Fork quadrangle, the unit is dominantly sandstone and lesser siltstone. The sandstone beds are light brown to dark rusty brown and mostly fine grained but locally coarse grained. A few channel-form, hard-pebble conglomeratic lenses are also present. Some of the sandstone beds are impure, containing biotite and other dark minerals and rock fragments. Most of the sandstones are poorly cemented and nonresistant; bedding features are seldom evident. Siltstone beds in the unit are mostly light brown to light gray, locally greenish gray. They are generally marly, and most contain varying amounts of carbonized plant fragments. A few thin light-gray-weathering marlstone beds are present in the unit, mostly in the northern part of its outcrop area. A thin 
persistent marlstone bed lies about $50-60 \mathrm{ft}(15-18 \mathrm{~m})$ below the top of the unit. Other marlstone beds appear to be nonpersistent. The unit in most places is nonresistant and forms slopes, but some of the more resistant sandstone and siltstone beds form conspicuous brown ledgy cliffs in the southeastern part of the Bull Fork quadrangle. The unit thins from about $380 \mathrm{ft}(116 \mathrm{~m})$ in the southwestern part of the Bull Fork quadrangle to about $80 \mathrm{ft}(24 \mathrm{~m})$ in the southeastern part of the quadrangle.

\section{Marker Bed at Bull Fork}

The marker bed at Bull Fork (map unit Tgbf) overlies Uinta unit $D$ (map unit Tud) of the Bull Fork quadrangle. Both of these units were mapped separately only in the Bull Fork quadrangle. The marker bed at Bull Fork is a persistent, conspicuous marlstone bed cropping out mostly on high ground of the Roan Plateau on the main divide between the Piceance Creek and Roan Creek drainages. The unit is present but not mapped separately in the southwestern part of the Cutoff Gulch quadrangle adjacent to the east. Equivalent rocks are present in the Mount Blaine quadrangle, adjacent to the south, but are included in the upper part of another mapped marlstone tongue, map unit Tgsl (see below).

The marlstone of the unit is a thin bed of light-gray to white variably silty, finely laminated, marlstone. The unit is about $30-60 \mathrm{ft}(9-18 \mathrm{~m})$ thick.

\section{Maristone at Jackrabbit Ridge}

A dominantly marlstone sequence is the informally designated marlstone at Jackrabbit Ridge (map unit Tgj). Within the report area, it was mapped only in the Circle Dot Gulch quadrangle where it is the uppermost of two tongues of the upper part of the Green River-Uinta intertonguing sequence (figs. 5 and 7). It is underlain by Uinta unit C (map unit Tuc), previously described, and is overlain by the main body of the Uinta Formation (designated map unit Tud in the Circle Dot Gulch quadrangle). Within the report area, the unit terminates southward along the northeast-trending pinchout line of the underlying Uinta tongue (map unit Tuc), described above, in the southern part of the Circle Dot Gulch quadrangle where the Jackrabbit Ridge unit merges with the Parachute Creek Member of the Green River Formation. The lower part of the marlstone at Jackrabbit Ridge is equivalent to the marlstone at Barnes Ridge (map unit $\mathrm{Tgb}$ ) as mapped to the north in the Cutoff Gulch quadrangle. The Bames Ridge unit equivalent was not mapped separately in the Mount Blaine quadrangle, adjacent on the west, but there is mapped with Uinta unit $C$ (map unit Tuc) previously described (fig. 5). Higher beds of the Jackrabbit Ridge unit are equivalent to the marlstone at Sleepy Ridge (map unit Tgsl) of the Mount Blaine quadrangle, described below.
The upper part of the Jackrabbit Ridge unit is a sequence of dominant marlstone intertongued with beds of sandstone or siltstone. Northward into the Cutoff Gulch quadrangle, the sandstone and siltstone are thicker and the marlstone thinner and siltier in the vicinity of the West Fork of Parachute Creek in the Cutoff Gulch quadrangle and do not extend much farther north before pinching out or phasing into sandstone and siltstone of the overlying main body of the Uinta Formation. For this reason, the mapping of the unit was arbitrarily terminated at the quadrangle boundary and not carried northward into the Cutoff Gulch quadrangle. The Jackrabbit Ridge unit, however, was mapped to the northeast and east in the McCarthy Gulch (O'Sullivan and others, 1981) and Forked Gulch (O'Sullivan and Hail, 1987) quadrangles. The marlstone at Jackrabbit Ridge is mostly marlstone, oil shale, lesser siltstone, and very fine grained sandstone. Channel sandstone is present locally. The marlstone beds include some lean oil shale, estimated at about 5-10 gallons per ton (20-40 liters per metric ton) in the extreme northern part of the Circle Dot Gulch quadrangle. Oil-shale values increase progressively to the south toward the line of merger with the Parachute Creek Member of the Green River Formation where the unit is dominantly oil shale. The marlstone beds are variably silty and weather light gray to light brown. The siltstone and sandstone beds are variably marly and tuffaceous, locally contain carbonized plant fragments, and weather light to medium brown. The unit locally is only moderately resistant but forms a series of benches and grooves on steep exposures. It thins from about $150 \mathrm{ft}(45$ $\mathrm{m}$ ) along Wolf Creek in the northwestern part of the Circle Dot Gulch quadrangle to about $40 \mathrm{ft}(12 \mathrm{~m})$ near Sheep Kill and Garden Gulches in the eastern part of the quadrangle.

\section{Marlstone at Sleepy Ridge}

The marlstone at Sleepy Ridge (map unit Tgsl) was mapped only in the Mount Blaine quadrangle of the report area. It was mapped in the northeastern part of the Desert Gulch quadrangle (Johnson, 1981a). It is equivalent to the marlstone at Jackrabbit Ridge (map unit Tgj) except that it does not include the lowermost beds of the Jackrabbit Ridge unit (fig. 5). Therefore the basal contact of the Sleepy Ridge unit is stratigraphically higher than that of the Jackrabbit Ridge unit. The unit is present throughout approximately the northem two-thirds of the Mount Blaine quadrangle. It terminates southward east of Clear Creek along the easttrending pinchout line of the underlying Uinta unit $C$ (map unit Tuc) where it merges with the Parachute Creek Member of the Green River Formation. West of Clear Creek, it terminates to the south by merger with the lower part of an undivided Green River tongue, map unit Tgss (fig. 5), the upper part of which is equivalent to the 
marlstone at Skinner Ridge (Tgsk). The marlstone at Sleepy Ridge is mostly overlain by the main body of the Uinta Formation (map unit Tud) or, on part of Skinner Ridge, by Uinta unit $\mathrm{E}$ (map unit Tue).

The marlstone at Sleepy Ridge is mostly lightgray-weathering marlstone including oil shale and lesser siltstone and sandstone. In the northern part of the Mount Blaine quadrangle, an upper and lower marlstone, generally barren of oil shale, are separated by a southward-thinning wedge of brown-weathering sandstone and siltstone. The upper marlstone was mapped separately in the Bull Fork quadrangle to the north as the marker bed at Bull Fork (map unit Tgbf), which was previously described. The sandstonesiltstone wedge is as much as $100 \mathrm{ft}(30 \mathrm{~m})$ thick at the northem boundary of the Mount Blaine quadrangle but thins abruptly and pinches out to the south. Elsewhere the unit consists mostly of several marlstone beds separated by siltstone or marly siltstone. The marlstones are mostly barren in the north but contain increasingly rich oil shale southward. The unit is mostly nonresistant. It thickens from about $40 \mathrm{ft}(12 \mathrm{~m})$ in the southern part of the Mount Blaine quadrangle to $200 \mathrm{ft}(60 \mathrm{~m})$ in the north.

\section{Uinta Unit E of the Mount Blaine Quadrangle}

Uinta unit $\mathrm{E}$ (map unit Tue) of the Mount Blaine quadrangle (figs. 5 and 6 ) is the highest Uinta tongue mapped in the report area. It was mapped on Skinner Ridge in the southwestem part of the Mount Blaine quadrangle of the report area. An equivalent unit was mapped in the Desert Gulch quadrangle (Johnson, 1981a) adjacent on the west. It overlies the marlstone at Sleepy Ridge (map unit Tgsl) and underlies the marlstone at Skinner Ridge (map unit Tgsk). It is mostly light-brown variably marly siltstone and minor fine-grained sandstone. It becomes increasingly marly southward and terminates as a mappable unit by facies change to marlstone. In the subsurface below the crest of Skinner Ridge, the southward termination line trends northwestward. Unit $E$ is about $50-90 \mathrm{ft}(15-28 \mathrm{~m})$ thick.

\section{Marlstone at Skinner Ridge}

The informally named marlstone at Skinner Ridge (map unit Tgsk) is the stratigraphically highest mapped Green River tongue in the report area and thus far the highest in the entire Piceance Creek basin. It was mapped on Skinner Ridge in the Mount Blaine quadrangle and in the adjacent Desert Gulch quadrangle to the west (Johnson, 1981a). Within the Mount Blaine quadrangle, it is present only along the northeastern side of Skinner Ridge and terminates southwestward at the northwest-trending termination line of the underlying Uinta unit $E$ (map unit Tue) of the Mount Blaine quadrangle.

The unit consists of light-gray-weathering marlstone including some lean oil shale and silty marlstone. It locally contains some thin papery oil-shale beds in its upper part and near the base. It is about $40-60 \mathrm{ft}(12-18 \mathrm{~m})$ thick.

\section{Marlstone at Sleepy Ridge and Marlstone at \\ Skinner Ridge Undivided}

This combined unit (map unit Tgss), the lateral equivalent of the marlstone at Sleepy Ridge and the marlstone at Skinner Ridge, occupies a small area on both the northeastern and southwestern sides of Skinner Ridge southward beyond the southem termination line of the Uinta unit $\mathrm{E}$ (map unit Tue) of the Mount Blaine quadrangle. The unit, in turn, merges a short distance to the southwest with the Parachute Creek Member of the Green River Formation. The unit is mostly light-gray-weathering marlstone including minor lean oil shale and silty marlstone. It is about 80-150 ft (24-46 m) thick.

\section{Main Body of the Uinta Formation}

Throughout the report area, all strata lying above the highest mapped tongue or member of the Green River Formation are assigned to the main body of the Uinta Formation (figs. 4-7). This includes Uinta unit $\mathrm{E}$ (map unit Tue) of the Bull Fork quadrangle, unit D (map unit Tud) of the Cutoff Gulch quadrangle, units D and F (map units Tud and Tuf) of the Mount Blaine quadrangle, and unit $D$ (map unit Tud) of the Circle Dot Gulch quadrangle. As thus defined, the base of the main body lies at different stratigraphic horizons in the report area. With some modification this usage is followed on the $1: 50,000$-scale geologic map (Hail and others, 1989) of the Roan Plateau area. The modification to the Roan Plateau map consists of projecting the marlstone at Jackrabbit Ridge-Uinta unit D contact northward from the Circle Dot Gulch quadrangle into the southwestern part of the Cutoff Gulch quadrangle and projecting the marker bed at Bull Fork-Uinta unit E contact eastward from the Bull Fork quadrangle into the Cutoff Gulch quadrangle as far east as the east boundary of township R. 97 W.

As here designated within the report area, the main body of the Uinta includes fairly abundant marlstone beds similar in lithology to the underlying tongues of the Green River Formation. These are, however, apparently nonpersistent and therefore are not regarded as tongues of the Green River Formation. Some silty marlstone of limited extent east of Clear Creek and south of Deer Park Gulch in the Mount Blaine quadrangle may be laterally equivalent to the marlstone at Skinner Ridge (map unit Tgsk) on Skinner Ridge west of Clear Creek, but it was not mapped separately and is included in the overlying main body of the Uinta (map unit Tud of the Mount Blaine quadrangle, fig. 5).

The rocks of the main body are similar to those of the various tongues previously described. Brown-weathering tuffaceous sandstone and siltstone predominate, and marlstone beds, including some oil shale, are fairly abundant. 
Minor limestone, conglomerate, shale, and claystone are also present. Paleoslump blocks of sandstone and siltstone are present locally throughout much of the report area. Minor erosional disconformities were observed in a few places.

The sandstene beds are highly variable in lithology, very fine to very coarse grained, and locally conglomeratic. Many are clean, quartzose sandstones; others contain abundant clay, rock grains, biotite, and other minerals. Many of the sandstones contain carbonized plant fragments. The sandstone beds are generally massive or show no distinctive bedding characteristics; some are parallel bedded and locally crossbedded. Minor channel-form conglomeratic sandstone beds are present locally; a few conglomerate beds include clay fragments and fossil wood. Lime-cemented spheroidal concretions are locally abundant, especially in the Bull Fork quadrangle. The siltstone beds are variably marly and commonly grade to silty marlstone. Most siltstone beds contain scattered carbonized plant fragments. Light-gray dolomitic marlstone beds are common, especially in the southern part of the report area, but are lenticular or nonpersistent. They are variably silty, and many grade laterally to marly siltstone. The marlstone beds locally contain oil shale, mostly in the southern part of the report area. A few of the oil-shale beds are relatively rich in places, but the beds are generally very thin and, like the enclosing marlstone beds, are lenticular, nonpersistent, and of no present economic value. Minor thin limestone beds are generally associated with the marlstone beds. Most of the rocks of the main body are nonresistant and weather to rounded slopes, but in many places where the sandstone and siltstone beds are strongly cemented they form resistant cliffs and ledges. The top of the main body is eroded, and the maximum remaining thickness is about 540 $\mathrm{ft}(165 \mathrm{~m})$.

\section{Quaternary Deposits}

Surficial deposits of Pleistocene and Holocene age include alluvium, alluvial fans, talus and slopewash, and landsides. These deposits were mapped separately on the four constituent $7 \frac{1}{2}$-minute quadrangle maps. On the 1:50,000-scale map of the Roan Plateau (Hail and others, 1989), the alluvium and alluvial fans were included in a single map unit.

The term alluvium includes locally derived mud, silt, sand, and gravel deposited by streams and mostly confined to the larger stream valleys. In the Bull Fork and Cutoff Gulch quadrangles the mapped alluvium (map unit Qal) also includes some alluvial fans at the mouths of branch streams and locally some slope wash along steep valley walls.

Alluvial fans (map unit Qf) were mapped separately from the valley floor alluvium (map unit Qa) in the Mount Blaine and Circle Dot Gulch quadrangles. These are composed of mostly nonsorted masses of mud, silt, sand, and gravel and locally include large blocks of broken bedrock. They are mostly the result of torrential flooding in short branch drainages or hillside gullies of high, steep cliffs along the major trunk streams. In some areas, as along Parachute Creek in the southeastern part of the Circle Dot Gulch quadrangle, coalescing fans form a continuous blanket along the valley margin. In many places, both on Clear Creek and Parachute Creek, fans originating on opposite sides of the valley join to completely cover the valley alluvium.

Talus and slopewash deposits (map unit $Q t$ ) are composed of locally derived, mostly unsorted detritus moved by gravity and sheet flooding. The deposits accumulate on the lower slopes of the high steep smooth canyon walls formed on the Parachute Creek, Garden Gulch, or Douglas Creek Members of the Green River Formation and derive their constituent material from these units. The deposits commonly include block-size material, much of which is marlstone of the Parachute Creek Member. Talus deposits are more common than those shown on the constituent $71 / 2$-minute geologic maps; only the larger, more extensive deposits are shown.

Landslide deposits (map unit Ql or Qls) consisting of block slides, large masses of incoherent detritus, and slumped ground are common. Slumped ground, slide masses of chaotic material, and block slides are common on the lower slopes of canyon walls along Clear Creek and its tributaries mostly in the Mount Blaine quadrangle. Most originate in the nonresistant rocks of the Douglas Creek Member of the Green River Formation. In the valley of Parachute Creek a few scattered landslide masses originate in the Anvil Points or Garden Gulch Members of the Green River Formation or in the Wasatch Formation.

\section{STRUCTURE}

The central Roan Plateau area is on the southwestern flank of the Piceance Creek basin, the deepest structural basin in Colorado (MacLachlan and Kleinkopf, 1969, pl. 1). The deepest part of the basin, about $18,000 \mathrm{ft}(5,500 \mathrm{~m})$ below sea level to Precambrian basement, is about $18 \mathrm{mi}(29$ $\mathrm{km}$ ) north of the report area. The depth to Precambrian basement within the area increases from about $7,500 \mathrm{ft}$ $(2,300 \mathrm{~m})$ below sea level at the southwestern corner of the area to about $14,000 \mathrm{ft}(4,000 \mathrm{~m})$ below sea level along the northern boundary of the area. Figure 8 shows the structure of the central Roan Plateau area based on the configuration of the top of the Mahogany oil-shale zone of the Parachute Creek Member of the Green River Formation. The structure of the area is fairly simple. Structural trends in the area are characteristic of those throughout most of the Piceance Creek basin. Fold axes and faults generally trend 


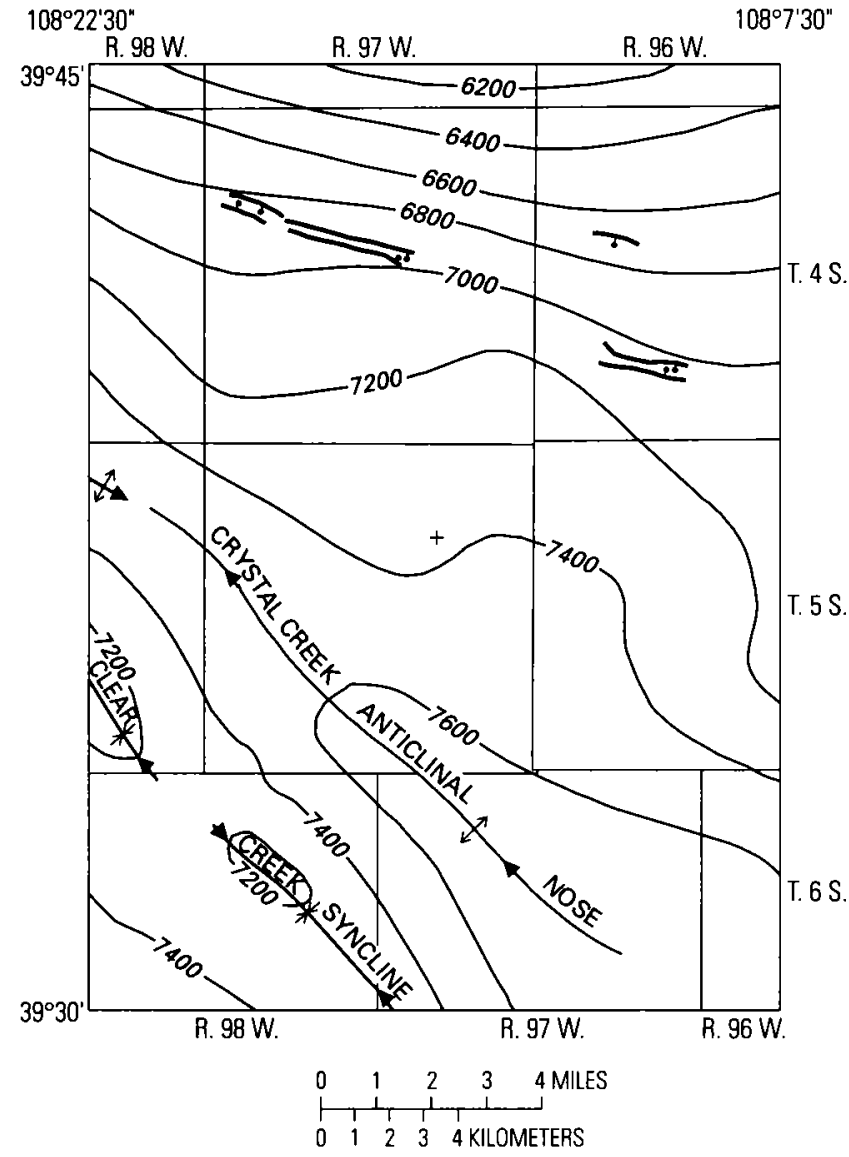

EXPLANATION

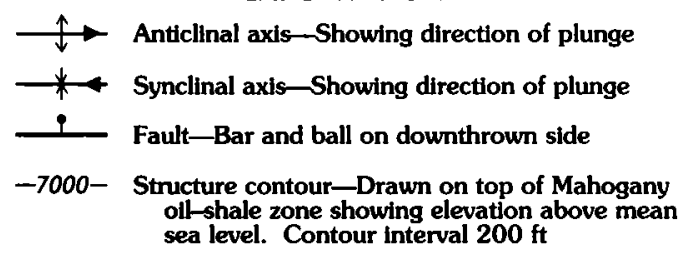

Figure 8. Structure of the central Roan Plateau area.

\section{Crystal Creek Anticlinal Nose and Clear Creek Syncline}

The northwest-trending fold system of the Crystal Creek anticlinal nose and the Clear Creek syncline begins near the Colorado River and extends northwestward for a distance of about $30 \mathrm{mi}(48 \mathrm{~km})$ across the entire southwestern part of the Piceance Creek basin, including the report area, and into Cretaceous rocks of the Douglas Creek arch area. (Waldron and others, 1951; Cashion, 1973; Pitman and Johnson, 1978; Hail and others, 1989).

The Crystal Creek anticlinal nose forms the southeastem element of an anticlinal fold that trends across the southwestern part of the Piceance Creek basin. The fold plunges northwestward and terminates near the western boundary of the report area in a structural saddle (fig. 8) that separates it from the southeast-plunging northwestem element of the fold. This anticline was termed the Douglas Creek anticline by Dyni (1969) and Cashion (1973) west of the report area. The short segment of this anticline within the report area, in the northern part of T. 5 S., R. 98 W., is not labelled on figure 8 .

It is probable that there is a reversal of plunge of the Crystal Creek anticlinal nose toward the southeast, along the crest of the anticline near the southern boundary of the area, and there may be as much as $150 \mathrm{ft}(45 \mathrm{~m})$ of structural closure in this vicinity (sec. 20, T. 6 S., R. 97 W.). The anticline is somewhat asymmetrical; it has steeper dips on its southwestern flank of about $200 \mathrm{ft} / \mathrm{mi}(40 \mathrm{~m} / \mathrm{km})$, and gentler dips on its northeastern flank of about $65 \mathrm{ft} / \mathrm{mi}(12$ $\mathrm{m} / \mathrm{km})$.

A part of the Clear Creek syncline (fig. 8) occupies the extreme southwestern part of the report area, the trace of its axis closely paralleling that of the Crystal Creek anticlinal nose to the northeast. Within the report area it is a broad shallow fold that includes one closed depression and part of a second along its axis. The structural closure on these probably does not exceed $100 \mathrm{ft}(30 \mathrm{~m})$.

\section{Faults}

northwesterly. The generally north to northeast dip of the rocks on the southwestern flank of the Piceance Creek basin is reversed in the southwestem part of the area by a single elongate, very low amplitude fold system formed by parts of the Crystal Creek anticlinal nose and the Clear Creek syncline. The maximum structural relief in the area as shown by the structure contours drawn on the Mahogany zone (fig. 8) is about $1,600 \mathrm{ft}(490 \mathrm{~m})$. The highest structural elevation, about $7,780 \mathrm{ft}(2,370 \mathrm{~m})$, is on the crest of the Crystal Creek anticlinal nose. The lowest elevation, about $6,180 \mathrm{ft}(1,880 \mathrm{~m})$, is on the northern boundary of the area. Dips on the nonfolded basin flank in the northern part of the report area are about $200 \mathrm{ft} / \mathrm{mi}(40 \mathrm{~m} / \mathrm{km})$.
There are no major faults in the central Roan Plateau area. Three narrow grabens are present along a northwesttrending facture zone in the northern part of the area. Maximum measured stratigraphic displacements on these faults do not exceed $120 \mathrm{ft}(37 \mathrm{~m})$; most are considerably less. The grabens are $1-2.5 \mathrm{mi}(1.6-4 \mathrm{~km})$ long and 200-1,200 ft $(60-370 \mathrm{~m})$ wide. Small northwest-striking faults (not shown on fig. 8) between the graben in the central part of T. 4 S., R. 97 W., and the graben in the southwestern part of T. 4 S., R. 96 W., suggest that the grabens lie along a single fracture zone that extends for a total distance of about $9 \mathrm{mi}(14.5 \mathrm{~km})$. 
Table 3. Oil-shale resources in the Bull Fork quadrangle

[Because of insufficient data, resources are not estimated for individual oil-shale zones below the following isovalue lines shown in barrels per acre: R-1 zone, 200,000; R-2 zone, 50,000; L-2 zone, 20,000; R-3 zone, 25,000; L-3 zone, 20,000; R-4 zone, 80,000; $\mathrm{L}-4$ zone, 50,000 . No resources are estimated in the $\mathrm{L}-1$ zone in areas containing less than 5 gallons per ton]

\begin{tabular}{lcccc}
\hline Zone & $\begin{array}{c}\text { Thickness } \\
\text { (feet) }\end{array}$ & $\begin{array}{c}\text { Gallons } \\
\text { per ton }\end{array}$ & Barrels per acre & $\begin{array}{c}\text { Approximate } \\
\text { total resource } \\
\text { (billions of barrels) }\end{array}$ \\
\hline Mahogany & $95-150$ & $25-28$ & $170,000-300,000$ & 8.5 \\
R-6 & $120-165$ & $16-25$ & $135,000-280,000$ & 7.8 \\
L-5 & $70-95$ & $7-13$ & $36,000-100,000$ & 2.3 \\
R-5 & $158-180$ & $13-19$ & $120,000-270,000$ & 7.0 \\
L-4 & $50-70$ & $9-16$ & $<50,000-80,000$ & 1.7 \\
R-4 & $70-90$ & $13-25$ & $76,000-168,000$ & 3.9 \\
L-3 & $28-45$ & $<5-7$ & $15,000-24,000$ & 0.1 \\
R-3 & $<30-70$ & $9-15$ & $<25,000-78,000$ & 1.2 \\
L-2 & $<40-100$ & $<5-8$ & $<20,000-50,000$ & 0.3 \\
R-2 & $<75-130$ & $<10-16$ & $<50,000-150,000$ & 2.1 \\
L-1 & $<90-135$ & $<5-6$ & $<45,000-53,000$ & 0.1 \\
R-1 & $18->400$ & $<15-22$ & $<200,000-425,000$ & 10.7 \\
\hline
\end{tabular}

Table 4. Oil-shale resources in the Cutoff Gulch quadrangle

[Because of insufficient data, resources are not estimated for individual oil-shale zones below the following isovalue lines shown in barrels per acre: R-1 zone, 200,000; R-2 zone, 50,000; L-2 zone, 20,000; R-3 zone, 25,000; L-3 zone, 20,000; L-4 zone, 50,000 . No resources are estimated in the $\mathrm{L}-1$ zone in areas containing less than 5 gallons per ton]

\begin{tabular}{lcccc}
\hline Thickness & Gallons \\
(feet) & per ton & Barrels per acre & $\begin{array}{c}\text { Approximate } \\
\text { total resource } \\
\text { (billions of barrels) }\end{array}$ \\
\hline Mahogany & $112-168$ & $26-29$ & $215,000-325,000$ & 9.9 \\
R-6 & $142-198$ & $19-27$ & $190,000-320,000$ & 9.3 \\
L-5 & $90-120$ & $8-13$ & $70,000-100,000$ & 3.1 \\
R-5 & $178-208$ & $12-19$ & $175,000-270,000$ & 7.9 \\
L-4 & $56-80$ & $9-15$ & $44,000-77,000$ & 2.0 \\
R-4 & $70-90$ & $15-26$ & $87,000-170,000$ & 4.4 \\
L-3 & $29-43$ & $5-8$ & $11,000-24,000$ & 0.1 \\
R-3 & $32-65$ & $8-15$ & $23,000-78,000$ & 1.4 \\
L-2 & $30-70$ & $3-10$ & $11,000-48,000$ & 0.2 \\
R-2 & $70-115$ & $5-16$ & $25,000-140,000$ & 2.2 \\
L-1 & $87-120$ & $1-5$ & $<10,000-50,000$ & 0.1 \\
R-1 & $240->400$ & $<15-21$ & $<200,000-350,000$ & 8.9 \\
\hline
\end{tabular}

\section{ECONOMIC GEOLOGY}

\section{Oil Shale}

Rich oil-shale deposits are present within the Parachute Creek and Garden Gulch Members of the Green River Formation. Most of the resources are in the Parachute Creek Member. Tables 3-6 show oil-shale resources for the Bull Fork, Cutoff Gulch, Mount Blaine, and Circle Dot Gulch quadrangles, respectively. The information in these tables is derived from published resource maps by Pitman
(1979), Pitman and Johnson (1978), and Pitman and others (1989). Oil-shale resources for oil-shale beds above the Mahogany zone (pls. 1 and 2) and below the R-1 zone (pl. 2) are not included in the resource tables. Pitman and Donnell (1973), however, showed that very large oil-shale resources are present above the Mahogany zone, especially in the southern part of the Piceance Creek basin. Based on their estimates, (Pitman and Donnell, 1973, table 1), oilshale resources within the report area in beds above the Mahogany zone containing at least 12 gallons per ton may exceed 40 billion barrels of oil. No estimates have been made for oil-shale resources in beds below the R-1 zone. 
Table 5. Oil-shale resources in the Mount Blaine quadrangle

[Because of insufficient data, resources are not estimated for individual oil-shale zones below the following isovalue lines shown in barrels per acre: $R-1$ zone, 200,000; R-2 zone, 50,000; L-2 zone, 20,000; R-3 zone, 25,000; L-3 zone, 20,000; R-4 zone, 80,000; $\mathrm{L}-4$ zone, 50,000; R-5 zone, 100,000; R-6 zone, 100,000. Resources are not estimated in the $L-1$ zone in areas containing less than 5 gallons per ton. $\mathrm{N}$ indicates oil-shale zone falls below these values]

\begin{tabular}{|c|c|c|c|c|}
\hline Zone & $\begin{array}{c}\text { Thickness } \\
\text { (feet) }\end{array}$ & $\begin{array}{l}\text { Gallons } \\
\text { per ton }\end{array}$ & Barrels per acre & $\begin{array}{c}\text { Approximate } \\
\text { total resource } \\
\text { (billions of barrels) }\end{array}$ \\
\hline Mahogany & $80-112$ & $22-25$ & $130,000-215,000$ & 4.3 \\
\hline$R-6$ & $120-142$ & $7-19$ & $<100,000-190,000$ & 2.3 \\
\hline $\mathbf{L}-5$ & $70-100$ & $5-10$ & $<25,000-68,000$ & 1.0 \\
\hline $\mathbf{R}-5$ & $110-180$ & $<10-13$ & $<100,000-170,000$ & 2.3 \\
\hline$L-4$ & $\mathbf{N}$ & $\mathbf{N}$ & $\mathbf{N}$ & $\mathbf{N}$ \\
\hline $\mathbf{R}-\mathbf{4}$ & $\mathbf{N}$ & $<10-15$ & $<80,000-86,000$ & 0.2 \\
\hline $\mathbf{L}-3$ & $\mathbf{N}$ & $\mathbf{N}$ & $\mathbf{N}$ & $\mathbf{N}$ \\
\hline $\mathbf{R}-\mathbf{3}$ & $\mathbf{N}$ & $\mathbf{N}$ & $\mathbf{N}$ & $\mathbf{N}$ \\
\hline $\mathrm{L}-2$ & $\mathbf{N}$ & $\mathbf{N}$ & $\mathbf{N}$ & $\mathbf{N}$ \\
\hline $\mathbf{R}-\mathbf{2}$ & $\mathbf{N}$ & $\mathbf{N}$ & $\mathbf{N}$ & $\mathbf{N}$ \\
\hline $\mathbf{L}-1$ & $\mathbf{N}$ & $\mathbf{N}$ & $\mathbf{N}$ & $\mathbf{N}$ \\
\hline $\mathbf{R}-\mathbf{1}$ & $\mathbf{N}$ & $\mathbf{N}$ & $\mathbf{N}$ & $\mathbf{N}$ \\
\hline
\end{tabular}

Table 6. Oitshale resources in the Circle Dot Gulch quadrangle

[Because of insufficient data, resources are not estimated for individual oil-shale zones below the following isovalue lines shown in barrels per acre: R-1 zone, 200,000; R-2 zone, 50,000; L-2 zone, 20,000; R-3 zone, 25,000; L-3 zone 20,000; R-4 zone, 80,000 ; $L-4$ zone, 50,$000 ; R-5$ zone, 100,000; R-6 zone, 100,000. Resources are not estimated in the $L-1$ zone in areas containing less than 5 gallons per ton. $\mathrm{N}$ indicates oil-shale zone falls below these values]

\begin{tabular}{lcccc}
\hline Zone & $\begin{array}{c}\text { Thickness } \\
\text { (feet) }\end{array}$ & $\begin{array}{c}\text { Gallons } \\
\text { per ton }\end{array}$ & Barrels per acre & $\begin{array}{c}\text { Approximate } \\
\text { total resource } \\
\text { (billions of barrels) }\end{array}$ \\
\hline Mahogany & $90-132$ & $22-26$ & $160,000-242,000$ & 5.3 \\
R-6 & $135-195$ & $7-21$ & $100,000-270,000$ & 3.7 \\
L-5 & $90-115$ & $5-10$ & $30,000-75,000$ & 1.5 \\
R-5 & $122-193$ & $10-13$ & $100,000-180,000$ & 3.8 \\
L-4 & $\mathrm{N}$ & $\mathrm{N}$ & $\mathrm{N}$ & $\mathbf{N}$ \\
R-4 & $\mathrm{N}$ & $1-15$ & $\mathbf{8 0 , 0 0 0 - 8 8 , 0 0 0}$ & $\mathbf{0 . 7}$ \\
L-3 & $\mathrm{N}$ & $\mathrm{N}$ & $\mathrm{N}$ & $\mathrm{N}$ \\
R-3 & $\mathrm{N}$ & $\mathrm{N}$ & $\mathrm{N}$ & $\mathrm{N}$ \\
L-2 & $\mathrm{N}$ & $\mathrm{N}$ & $\mathrm{N}$ & $\mathrm{N}$ \\
$\mathrm{R}-2$ & $\mathrm{~N}$ & $\mathrm{~N}$ & $\mathrm{~N}$ & $\mathrm{~N}$ \\
L-1 & $\mathrm{N}$ & $\mathrm{N}$ & $\mathrm{N}$ & $\mathrm{N}$ \\
$\mathrm{R}-1$ & $\mathrm{~N}$ & $\mathrm{~N}$ & $\mathrm{~N}$ & $\mathrm{~N}$ \\
\hline
\end{tabular}

Oil-shale-bearing rocks of the Green River Formation within the report area lie mostly on the southern or western flank of the Piceance Creek depositional basin. Depositional troughs or centers for all the oil-shale zones above R-2 are north or east of the report area (Pitman and others, 1989). Oil-shale values and thicknesses of these zones decrease sharply away from the depositional centers. As a result, the larger proportion of oil-shale resources shown in tables 3-6 is in the northern half of the report area, as are most of the oil-shale test drill holes. The few drill holes in the southem half of the area do not penetrate the lower oil-shale zones, and subsurface information is therefore sparse. The cutoffs and other limitations on resource information for the southern part of the area are shown on the resource maps by Pitman (1979), Pitman and Johnson (1978), and Pitman and others (1989) and given in the resource tables. The total oil-shale resources in the central Roan Plateau, as shown in tables 3-6, are about 120 billion barrels of oil.

Table 7 lists all the known oil-shale test drill holes in the report area by township and range. Locations of some of the drill holes, as noted, are not shown on the constituent 7-minute geologic maps (see fig. 1). The USGS core-hole 
Table 7. Oil-shale test drill holes, central Roan Plateau area

[N.D. indicates stratigraphic position not determined or proprietary]

\begin{tabular}{|c|c|c|}
\hline \multirow[b]{2}{*}{ Company and name } & \multirow[b]{2}{*}{ Location } & $\begin{array}{c}\text { Stratigraphic position } \\
\text { (oil-shale zone) }\end{array}$ \\
\hline & & Quadrangle \\
\hline \multicolumn{3}{|c|}{ T. 3 S., R. 97 W. } \\
\hline Occidental 2-49 ...........................1113 & SE $1 / 4$ sec. 32 & 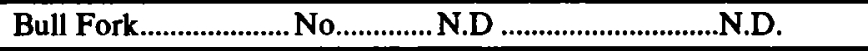 \\
\hline \multicolumn{3}{|c|}{ T. 3 S, R. 98 W. } \\
\hline Humble Hunter Creek 1.............C-233 & SE $1 / 4$ sec. 36 & Bull Fork.................... Yes ............ Above Mahogany.......Below R-1 \\
\hline \multicolumn{3}{|c|}{ T. 4 S, R 96 W. } \\
\hline Tosco TG 71-4................................ & SWL/4 sec. 6 & Cutoff Gulch .............. Yes ............ Above Mahogany .......R-1 \\
\hline Wasatch Bute 2 .............................119 & SW1/4 sec. 6 & Cutoff Gulch ............. Yes ............ Above Mahogany......B groove \\
\hline Tosco Bute 25 ................................8-82 & $\mathrm{NE} 1 / 4$ sec. 9 & Cutoff Gulch ............... No...............Above Mahogany.......R-6 \\
\hline Tosco Bute 14-727 .......................C-193 & $N W 1 / 4$ sec. 14 & Cutoff Gulch ............. Yes ............Above Mahogany.......R-6 \\
\hline Tell Ertl Bute ...............................C-49 & $\mathrm{NE} / 4 / 4$ sec. 16 & Cutoff Gulch ............. Yes ............Above Mahogany .......B groove \\
\hline Wasatch Bute 1.............................. -118 & SE $1 / 4$ sec. 17 & Cutoff Gulch ............. Yes ............ Above Mahogany .......B groove \\
\hline 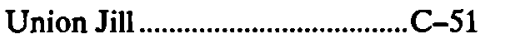 & NW1/4 sec. 23 & Cutoff Gulch ............. Yes ............ Above Mahogany .......Mahogany \\
\hline 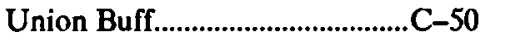 & $\mathrm{SE} 1 / 4$ sec. 23 & Cutoff Gulch ............. Yes ............ Above Mahogany .......Mahogany \\
\hline Union Rett ..................................... -52 & NW1/4 sec. 28 & Cutoff Gulch ............. Yes ........... Above Mahogany .......Mahogany \\
\hline Union Twigg.................................5-53 & SE $1 / 4$ sec. 35 & Cutoff Gulch ............ Yes ........... Above Mahogany......Mahogany \\
\hline \multicolumn{3}{|c|}{ T. 4 S, R. $97 \mathrm{~W}$. } \\
\hline Carter Willow Creek 3..............C-327 & SE $1 / 4 \sec .4$ & Bull Fork.................................... Above Mahogany.......Below R-1 \\
\hline Wasatch Princess Ann 1 ............C-168 & NWY/4 sec. 21 & Bull Fork..................... Yes ............ Above Mahogany ......R-6 \\
\hline Humble East Willow Creek 1..C-232 & NE $1 / 4$ sec. 28 & Bull Fork..................................... Above Mahogany .......Below R-1 \\
\hline Wasatch Washington 1 ..............C-169 & $\mathrm{NE} 1 / 4$ sec. 30 & Bull Fork................... Yes ............ Above Mahogany.......Mahogany \\
\hline Wasatch Washington 2 ..............C-120 & SWL/4 sec. 31 & Bull Fork................... Yes ........... Above Mahogany .......B groove \\
\hline Wasatch Carbon 1 .......................C-167 & $\mathrm{NE} 1 / 4$ sec. 33 & Bull Fork..................... Yes .............Above Mahogany .......R-6 \\
\hline Wasatch Tom ..............................C-295 & SWY/4 sec. 35 & 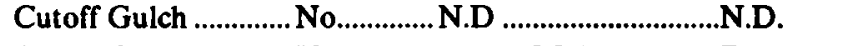 \\
\hline Wasatch Elizabeth 1...................C-123 & NE1/4 sec. 36 & Cutoff Gulch ............. Yes ............ Above Mahogany .......B groove \\
\hline General 32-36.............................. -122 & NE1/4 sec. 36 & Cutoff Gulch ............. Yes ............ Above Mahogany......R-6 \\
\hline \multicolumn{3}{|c|}{ T. 4 S, R. 98 W. } \\
\hline Carter West Willow 1.................C-311 & SWY/4 sec. 2 & Bull Fork...................... No.............. Above Mahogany .......Below R-1 \\
\hline Tosco Ohio 3...............................1036 & $\mathrm{NE} 1 / 4$ sec. 23 & Bull Fork...................................... Above Mahogany .......R-6 \\
\hline Savage Hunter.................................. -124 & NW1/4 sec. 23 & Bull Fork ....................................... Above Mahogany .......R-6 \\
\hline Savage Whiskey .............................. -125 & NE1/4 sec. 24 & Bull Fork................... Yes ........... Above Mahogany .......B groove \\
\hline Tosco & SWY/4 sec. 25 & 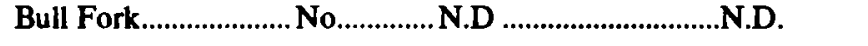 \\
\hline Savage Camp.................................. -126 & SEY 14 sec. 35 & Bull Fork..................... Yes ............ Above Mahogany .......L-5 \\
\hline \multicolumn{3}{|c|}{ T. 5 S, R. 96 W. } \\
\hline Union Blackbird .............................. -83 & NWY $/ 4$ sec. 7 & Cutoff Gulch ............. Yes ............ Above Mahogany .......B groove \\
\hline Union French ................................. -84 & NE1/4 sec. 7 & Cutoff Gulch ............. Yes ............ Above Mahogany....... B groove \\
\hline Union Parachute............................8-85 & NWY/4 sec. 9 & Cutoff Gulch ............. Yes ........... Above Mahogany .......B groove \\
\hline Chevron C-1A ...............................1191 & NE1/4 sec. 19 & 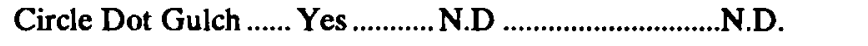 \\
\hline Chevron PC-24 .............................. -396 & $\mathrm{NW} 1 / 4$ sec. 20 & 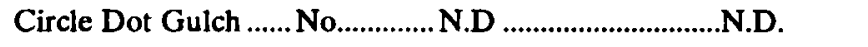 \\
\hline Pacific Burbank................ & NE1/4 sec. 22 & Circle Dot Gulch ...... Yes ............. Above Mahogany .....R-6 \\
\hline Chevron C-2 ................................1192 & NE1/4 sec. 29 & Circle Dot Gulch ...... Yes ............ N.D ................................. \\
\hline Chevron PC-25...........................C-397 & NE $1 / 4$ sec. 30 & 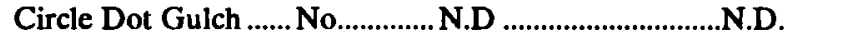 \\
\hline Chevron PC-21 ...............................394 & NE1/4 sec. 31 & 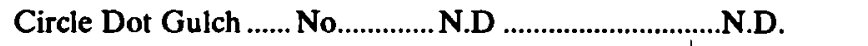 \\
\hline Union Jann ..................................87 & NE1/4 sec. 33 & Circle Dot Gulch ...... Yes ........... Above Mahogany.......Mahogany \\
\hline Chevron PC-2 .............................. -387 & SWy/4 sec. 33 & 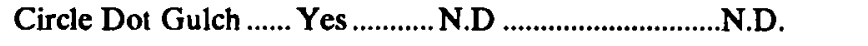 \\
\hline Union Land 3A .......................... -414 & SWY/4 sec. 17 & Circle Dot Gulch ....... No.............. Above Mahogany.......R-6 \\
\hline
\end{tabular}


Table 7. Oil-shale test drill holes, central Roan Plateau area-Continued

\begin{tabular}{|c|c|c|}
\hline \multirow{3}{*}{ Company and name } & \multirow[b]{2}{*}{ Location } & $\begin{array}{c}\text { Stratigraphic position } \\
\text { (oil-shale zone) }\end{array}$ \\
\hline & & Quadrangle \\
\hline & \multicolumn{2}{|c|}{ T. 5 S, R. 97 W. } \\
\hline 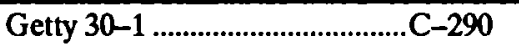 & SE $1 / 4$ sec. 1 & 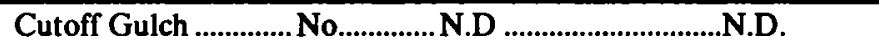 \\
\hline Tidewater Getty $11-2 \ldots \ldots \ldots \ldots . . . . . . C-280$ & $N W 1 / 4$ sec. 2 & 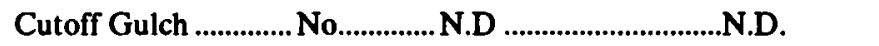 \\
\hline Sun Summer's Camp 3..............C-88 & SE $1 / 4$ sec. 2 & Cutoff Gulch ............. Yes ............Above Mahogany ......R-3 \\
\hline 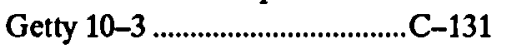 & $\mathrm{NE} 1 / 4 \sec .3$ & Bull Fork.................. Yes ........... Above Mahogany......B groove \\
\hline Tidewater Getty 9-4D ..............C-351 & $\mathrm{NE} 1 / 4$ sec. 4 & Bull Fork.................... Yes ............Above Mahogany ......L-2 \\
\hline 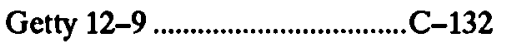 & SE $1 / 4$ sec. 9 & Mount Blaine ............ Yes ............ Above Mahogany ......R-6 \\
\hline 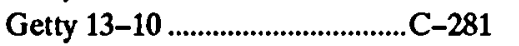 & NE $1 / 4$ sec. 10 & 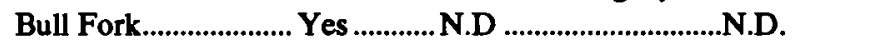 \\
\hline 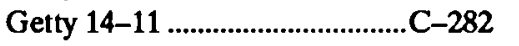 & NWY/4 sec. 11 & 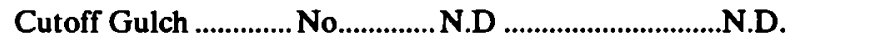 \\
\hline 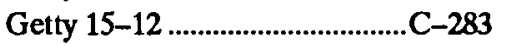 & $S W y_{4} \sec .12$ & 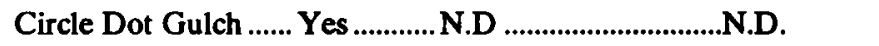 \\
\hline 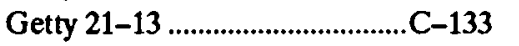 & $\mathrm{NW} 1 / 4 \sec .13$ & Circle Dot Gulch ...... Yes ........... Above Mahogany ......R-6 \\
\hline 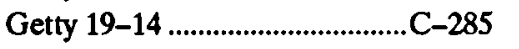 & $\mathrm{NE} 1 / 4$ sec. 14 & 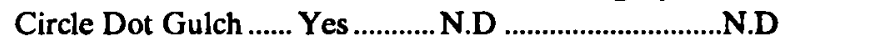 \\
\hline 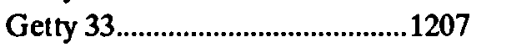 & SW1/4 sec. 14 & 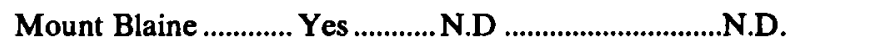 \\
\hline 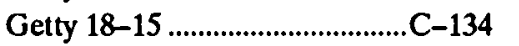 & NE $1 / 4$ sec. 15 & Mount Blaine ............ Yes ........... Above Mahogany ......R-6 \\
\hline 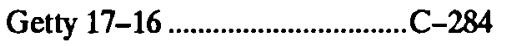 & $\mathrm{NE} 1 / 4$ sec. 16 & Mount Blaine ........... Yes ............... \\
\hline 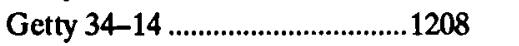 & SEY/4 sec. 16 & 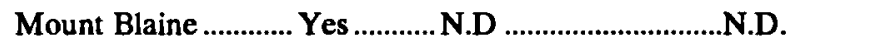 \\
\hline 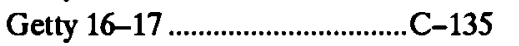 & $\mathrm{NE} 1 / 4$ sec. 17 & Mount Blaine ............ Yes ........... Above Mahogany ......R-6 \\
\hline 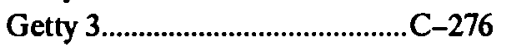 & SWY/4 sec. 19 & 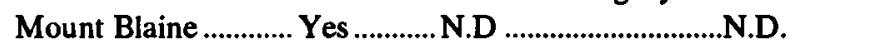 \\
\hline Sun Mager's Camp 2 .................C-89 & $N W 1 / 4$ sec. 20 & Mount Blaine ............ Yes ........... Above Mahogany ......R-6 \\
\hline 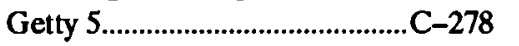 & $\mathrm{SE} / 4$ sec. 20 & Mount Blaine ........... Yes ............. \\
\hline 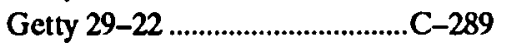 & SE $1 / 4 \sec .22$ & 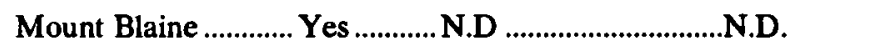 \\
\hline 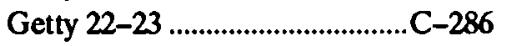 & SE $1 / 4$ sec. 23 & 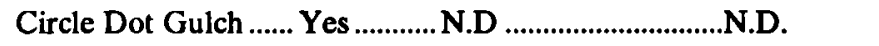 \\
\hline 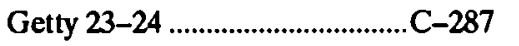 & SE $1 / 4$ sec. 24 & 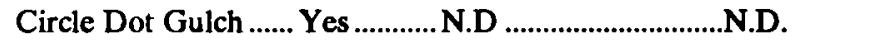 \\
\hline 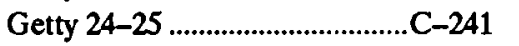 & $\mathrm{NE} / 4 / 4$ sec. 25 & 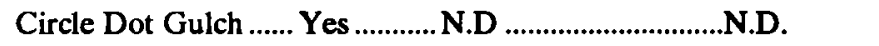 \\
\hline Sun Bear Run 1.............................90 & NW1/4 sec. 25 & Circle Dot Gulch ...... Yes ........... Above Mahogany ......R-6 \\
\hline 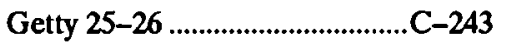 & SEY/4 sec. 26 & 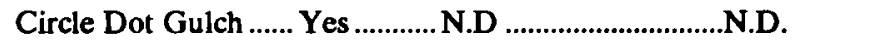 \\
\hline Chevron 32, 32A (Getty) ..........C-333 & NEY/4 sec. 27 & Mount Blaine ........... Yes ........... Above Mahogany ......R-3 \\
\hline Getty 7-28 & SE $1 / 4$ sec. 28 & 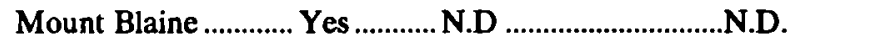 \\
\hline 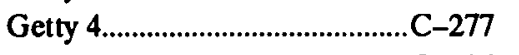 & SW1/4 sec. 29 & Mount Blaine ............ Yes ........... N.D .......................... N.D. \\
\hline 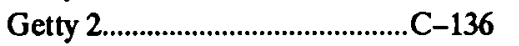 & $\mathrm{SW} 1 / 4$ sec. 30 & Mount Blaine ............ Yes ........... Above Mahogany ......B groove \\
\hline 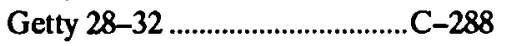 & NE $1 / 4$ sec. 32 & 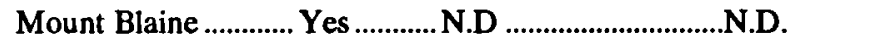 \\
\hline 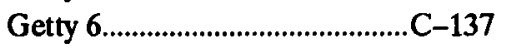 & SW1/4 sec. 33 & Mount Blaine ........... Yes ........... Above Mahogany ....... B groove \\
\hline 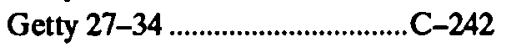 & NW1/4 sec. 34 & 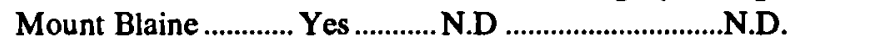 \\
\hline 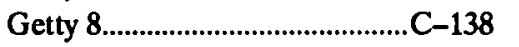 & NW1/4 sec. 35 & Mount Blaine ............ Yes ........... Above Mahogany .......B groove \\
\hline Cities Service CH-2 ....................1209 & SE $1 / 4$ sec. 35 & 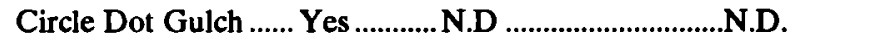 \\
\hline 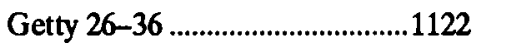 & $\mathrm{NE} / 4$ sec. 36 & 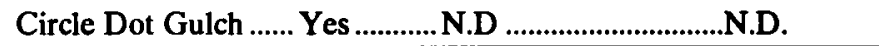 \\
\hline \multicolumn{3}{|c|}{ T. 5 S, R 98 W. } \\
\hline Pacific Wheeler 1........................C-93 & NW1/4 sec. 12 & Bull Fork..................... Yes ............ Above Mahogany .......R-6 \\
\hline 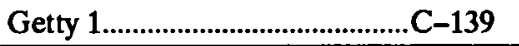 & SE1/4 sec. 23 & Mount Blaine ............ Yes ............ Above Mahogany ......R-6 \\
\hline \multicolumn{3}{|c|}{ T. 6 S., R. 96 W. } \\
\hline Pacific Dragert 1........................... -100 & $\mathrm{SW} / 4 \sec .5$ & Circle Dot Gulch ...... Yes ............ Above Mahogany ......R-6 \\
\hline Chevron PC-16............................ -392 & SWL/4 sec. 5 & 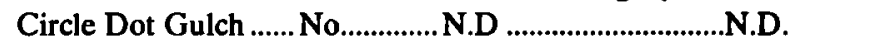 \\
\hline Chevron C-3 ................................1197 & SE $1 / 4 \sec .6$ & 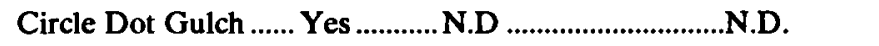 \\
\hline Chevron PC-18.............................393 & $N W y / 4$ sec. 6 & 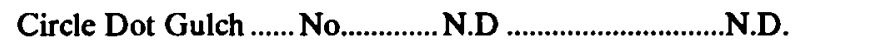 \\
\hline Chevron PC-8...............................389 & NWY/4 sec. 18 & 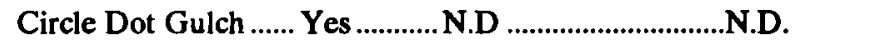 \\
\hline Pacific Midland 1..........................106 & SWY/4 sec. 18 & Circle Dot Gulch ...... Yes ........... Above Mahogany ......Mahogany \\
\hline
\end{tabular}


Table 7. Oitshale test drill holes, central Roan Plateau area-Continued

\begin{tabular}{|c|c|c|}
\hline \multirow{3}{*}{ Company and name } & \multirow[b]{2}{*}{ Location } & $\begin{array}{c}\text { Stratigraphic position } \\
\text { (oil-shale zone) }\end{array}$ \\
\hline & & Quadrangle \\
\hline & \multicolumn{2}{|c|}{ T. 6 S, R. 97 W. } \\
\hline Chevron PC-3............................1199 & SWY/4 sec. 1 & Circle Dot Gulch ...... Yes ............N.D ............................... \\
\hline Chevron PC-1 .............................1200 & NE $1 / 4$ sec. 2 & 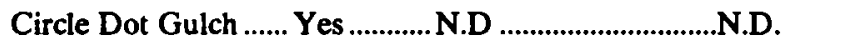 \\
\hline Chevron PC-10..............................390 & SWY/4 sec. 2 & 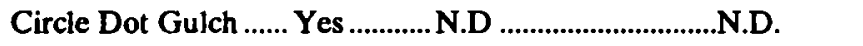 \\
\hline Cities Service CH-3 ...................1210 & SE1/4 sec. 3 & 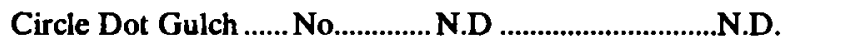 \\
\hline Pacific Magor 2 ..............................107 & SE $1 / 4$ sec. 7 & Mount Blaine ............ Yes ........... Above Mahogany......L-5 \\
\hline Cities Service Cascade 1 .............C-159 & $\mathbf{N W} / 4 \sec .10$ & Circle Dot Gulch ...... Yes ............ Above Mahogany .......R-6 \\
\hline Chevron PC-4 ..............................1202 & SWY/4 sec. 11 & Circle Dot Gulch ...... Yes ........... N.D ............................... \\
\hline Chevron C -4 ...................................1201 & SWY/4 sec. 11 & 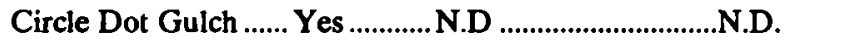 \\
\hline Chevron PC-12.............................. -391 & $\mathrm{NE} 1 / 4$ sec. 12 & 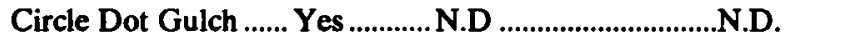 \\
\hline Chevron PC-9..............................1203 & NWY/4 sec. 12 & 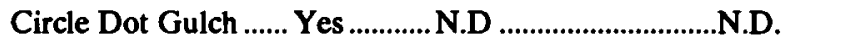 \\
\hline Chevron PC-6.............................1205 & $\mathrm{NW} / 4$ sec. 13 & 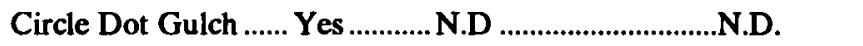 \\
\hline Chevron PC-7 .................................... & SW1/4 sec. 13 & 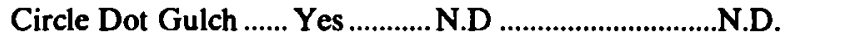 \\
\hline Chevron PC-5 ................................1206 & $\mathrm{NE} 1 / 4$ sec. 14 & Circle Dot Gulch ...... Yes .............. \\
\hline Chevron PC-22.............................. -395 & NWY/4 sec. 14 & 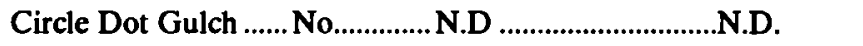 \\
\hline Pacific Pratt 1 & SWY/4 sec. 14 & Circle Dot Gulch ...... Yes ............ Above Mahogany ......R-5 \\
\hline Cities Service CH-5 ....................1211 & SE1/4 sec. 22 & Circle Dot Gulch ...... Yes ............. N.D \\
\hline \multicolumn{3}{|c|}{ T. 6 S, R. 98 W. } \\
\hline Texaco DeBeque A-2 ................1212 & $\mathrm{NE} 1 / 4 \sec .7$ & Mount Blaine ............. Yes ............... ................................ \\
\hline Mobil DH-2 ..............................1106 & SE $1 / 4$ sec. 13 & 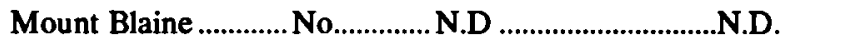 \\
\hline Pacific Magor 1 ............................C-101 & SWY/4 sec. 14 & Mount Blaine ............ Yes ............ Above Mahogany ......B groove \\
\hline Mobil DH-8 ...................................383 & SE $1 / 4$ sec. 1 & 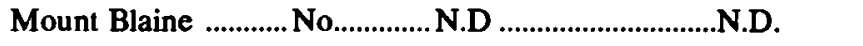 \\
\hline Pacific Scott 1 ................................ -102 & $\mathrm{NE} 1 / 4$ sec. 17 & Mount Blaine ............. No.............Above Mahogany ......B groove \\
\hline Pacific Magor 3 .............................. -103 & SW $1 / 4$ sec. 24 & Mount Blaine ........... Yes ........... Above Mahogany ......B groove \\
\hline Mobil DH-9 ..................................371 & $\mathrm{NE} 1 / 4$ sec. 25 & Mount Blaine ............................ ............................... \\
\hline Mobil DH-5 ............................1109 & $\mathrm{SW} 1 / 4 \mathrm{sec} .25$ & 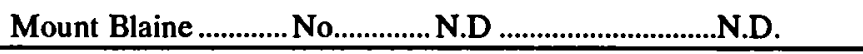 \\
\hline
\end{tabular}

numbers in column 2 of table 7 are the identification numbers for Colorado oil-shale drill holes in the U.S. Geological Survey computer storage and retrieval program for oil shale.

\section{Oil and Gas}

Oil and gas test drill holes for which records are available in the report area are shown in table 8 . There has been no recorded oil or gas production in the area. Small amounts of gas have been found in alluvial rocks of the upper part of the Upper Cretaceous Mesaverde Formation and in the lower part of the Wasatch Formation.

\section{REFERENCES CITED}

Bradley, W.H., 1931, Origin and microfossils of the oil shale of the Green River Formation of Colorado and Utah: U.S. Geological Survey Professional Paper 168, 58 p.

Brobst, D.A., and Tucker, J.D., 1973, X-ray mineralogy of the Parachute Creek Member, Green River Formation in the northern Piceance Creek basin, Colorado: U.S. Geological Survey Professional Paper 803, 53 p.
Cashion, W. B., 1973, Geologic and structure map of the Grand Junction quadrangle, Colorado and Utah: U.S. Geological Survey Miscellaneous Investigations Map I-736, scale $1: 250,000$.

Cashion, W.B., and Donnell, J.R., 1974, Revision of nomenclature of the upper part of the Green River Formation, Piceance Creek basin, Colorado, and eastem Utah: U.S. Geological Survey Bulletin 1394-G, p. G1-G9.

Donnell, J.R., 1953, Roadlog, side trip to oil shale plant, in Guidebook, northwestern Colorado: Rocky Mountain Association of Geologists Field Conference, 4th, p. 16-17. 1961, Tertiary geology and oil-shale resources of the Piceance Creek Basin between the Colorado and White Rivers, northwestern Colorado: U.S. Geological Survey Bulletin 1082-L, p. 835-891.

1969, Paleocene and lower Eocene units in the southern part of the Piceance Creek Basin, Colorado: U.S. Geological Survey Bulletin 1247-M, 18 p.

Donnell, J.R., and Blair, R.W., Jr., 1970, Resource appraisal of three rich oil-shale zones in the Green River Formation, Piceance Creek basin, Colorado: Colorado School of Mines Quarterly, v. 65, no. 4, p. 73-87.

Duncan, D.C., and Belser, Carl, 1950, Geology and oil-shale resources of the eastern part of the Piceance Creek Basin, Rio Blanco and Garfield Counties, Colorado: U.S. Geological Survey Oil and Gas Investigations Map OM-119. 
Table 8. Oil and gas drill holes, central Roan Plateau area [N.D., not determined. Total depth in feet]

\begin{tabular}{|c|c|c|c|}
\hline Location & $\begin{array}{l}\text { Total } \\
\text { depth }\end{array}$ & $\begin{array}{cc}\begin{array}{c}\text { Formation at } \\
\text { total depth }\end{array} & \begin{array}{l}\text { Year } \\
\text { drilled }\end{array} \\
\end{array}$ & Comments \\
\hline Equity Oil 9 South Piceance Creek ................ SE1/4 sec. 35, T. 3 S., R. 96 W. & 5,848 & Tongue of Uinta...Wasatch...............1962 & Abandoned \\
\hline J.M. Huber 2-1 Federal Brooks ...................... NW1/4 sec. 2, T. 4 S., R. 96 W. & 5,777 & Tongue of Uinta....Wasatch............... 1971 & Abandoned \\
\hline Continental Oil 7-1 Federal........................... NW1/4 sec. 7, T. 4 S., R. 97 W. & 1,004 & Tongue of Uinta....Green River........1973 & Abandoned \\
\hline Continental Oil 7-2 Federal............................ NW1/4 sec. 7, T. 4 S., R. 97 W. & 6,306 & Tongue of Uinta....Mesaverde .......... 1973 & Abandoned \\
\hline Gabbs Exploration 2 Thurman Gov't. .......... SE1/4 sec.10, T. 4 S., R. 97 W. & 7,215 & Tongue of Uinta....Mesaverde .......... 1958 & Abandoned \\
\hline F.A. Thurman 1 Government ......................... NE1/4 sec. 16, T. 4 S., R. 97 W. & 6,107 & Tongue of Uinta....Mesaverde .......... 1956 & Abandoned ......Gas in Wasatch, Mesaverde \\
\hline Gabbs Exploration 3 Thurman Gov't. ........... SW1/4 sec. 17, T. 4 S., R. 97 W. & 5,808 & Tongue of Uinta.....Mesaverde .......... 1960 & Abandoned .......Gas in Wasatch \\
\hline Gabbs Exploration 4 Thurman Gov't. .......... SE1/4 sec. 19, T. 4 S., R. 97 W. & 5,541 & Tongue of Uinta.... Wasatch.................1961 & Abandoned ......Gas in Wasatch \\
\hline Skelly Oil 1 Unit Dry Fork ............................ SEY/4 sec. 25, T. 4 S., R. 97 W. & 7,992 & Tongue of Uinta....Mesaverde .......... 1960 & Abandoned \\
\hline Continental Oil 1 Willow.................................... NE1/4 sec. 28, T. 4 S., R. 97 W. & 6,498 & Tongue of Uinta....Mesaverde .......... 1973 & Abandoned .......Gas in Mesaverde \\
\hline Lario Oil and Gas 1 Willow Creek Gov't..... SE1/4 sec. 12, T. 4 S., R. 98 W. & 5,760 & Tongue of Uinta....Wasatch................ 1968 & Abandoned \\
\hline Shannon Oil 1 Gov't......................................... SE1/4 sec. 13, T. 4 S., R. 98 W. & 6,211 & Tongue of Uinta....Mesaverde .......... 1959 & Abandoned ......Gas in Wasatch \\
\hline Barrett Energy C-1 Crystal Creek ................. NE1/4 sec. 12, T. 5 S., R. 97 W. & 2,053 & Tongue of Uinta....Green River........N.D. & N.D. \\
\hline Chevron Oil 1 Pacific ........................................ NW1/4 sec. 13, T. 5 S., R. 98 W. & 8,612 & Tongue of Uinta....Mancos Shale .... 1965 & Abandoned \\
\hline Barrett Energy A-2 Crystal Creek .................. NWY4 sec. 23, T. 6 S., R. 97 W. & 9,856 & Uinta ......................Mancos Shale ....N.D. & N.D. \\
\hline Sinclair Oil Co. 1 Haystack Mountain ..........SWy/4 sec. 23, T. 6 S., R. 97 W. & 733 & Uinta .......................Green River........ 1959 & N.D. \\
\hline
\end{tabular}


Duncan, D.C., and Denson, N.M., 1949, Geology of Naval Oil Shale Reserves 1 and 3, Garfield County, Colorado: U.S. Geological Survey Preliminary Map 94.

Duncan, D.C., Hail, W.J., Jr., O'Sullivan, R.B., and Pipiringos, G.N., 1974, Four newly named tongues of Eocene Green River Formation, northern Piceance Creek basin, Colorado: U.S. Geological Survey Bulletin 1394-F, p. F1-F13.

Dyni, J.R., 1969, Structure of the Green River Formation, northern part of Piceance Creek basin, Colorado: Mountain Geologist, v. 6, no. 2, pl. 1.

Hail, W.J., Jr., 1975, Preliminary geologic map of the Cutoff Gulch quadrangle, Rio Blanco and Garfield Counties, Colorado: U.S. Geological Survey Miscellaneous Field Studies Map MF-691, scale 1:24,000.

1977a, Preliminary geologic map of the Bull Fork quadrangle, Rio Blanco and Garfield Counties, Colorado: U.S. Geological Survey Miscellaneous Field Studies Map MF-830, scale 1:24,000.

1977b, Stewart Gulch Tongue-A new tongue of the Eocene Green River Formation, Piceance Creek basin, Colorado: U.S. Geological Survey Bulletin 1422-E, 8 p.

1978, Preliminary geologic map of the Mount Blaine quadrangle, Garfield County, Colorado: U.S. Geological Survey Miscellaneous Field Studies Map MF-984, scaie $1: 24,000$.

1982, Preliminary geologic map of the Circle Dot Gulch quadrangle, Garfield County, Colorado: U.S. Geological Survey Miscellaneous Field Studies Map MF-1293, scale 1:24,000.

1990, Geology of the lower Yellow Creek area, northwestern Colorado: U.S. Geological Survey Bulletin $1787-0,45 \mathrm{p}$.

Hail, W.J., Jr., O'Sullivan, R.B., and Smith, M.C., 1989, Geologic map of the Roan Plateau area, northwestern Colorado: U.S. Geological Survey Miscellaneous Field Investigations Map I-1797-C, scale 1:50,000.

Johnson, R.C., 1975, Preliminary geologic map, oil shale yield histograms, and stratigraphic sections, Long Point quadrangle, Garfield County, Colorado: U.S. Geological Survey Miscellaneous Field Studies Map MF-688, scale $1: 24,000$.

1977a, Preliminary geologic map of The Saddle quadrangle, Garfield County, Colorado: U.S. Geological Survey Miscellaneous Field Studies Map MF-829, scale $1: 24,000$.

1977b, Preliminary geologic map of the Figure Four Spring quadrangle, Rio Blanco and Garfield Counties, Colorado: U.S. Geological Survey Miscellaneous Field Studies Map MF-912, scale 1:24,000.

1981a, Preliminary geologic map of the Desert Gulch quadrangle, Garfield County, Colorado: U.S. Geological Survey Miscellaneous Field Studies Map MF-1328, scale $1: 24,000$.

1981b, Stratigraphic evidence for a deep Eocene Lake Uinta, Piceance Creek Basin, Colorado: Geology, v. 9, no. 2, p. $55-62$.

Evolution of Sedimentary Basins_-Uinta and Piceance Basins
1984, New names for units in the lower part of the Green River Formation, Piceance Creek basin, Colorado: U.S. Geological Survey Bulletin 1529-I, 20 p.

MacLachlan, J.C., and Kleinkopf, M.D., eds., 1969, Configuration of the Precambrian surface of Colorado: The Mountain Geologist, v. 6, no. 4, map.

O'Sullivan, R.B., 1975, Coughs Creek Tongue-A new tongue of the Eocene Green River Formation, Piceance Creek basin, Colorado: U.S. Geological Survey Bulletin 1395-G, 7 p.

O'Sullivan, R.B., and Hail, W.J., Jr., 1987, Preliminary geologic map of the Forked Gulch quadrangle, Garfield County, Colorado: U.S. Geological Survey Miscellaneous Field Studies Map MF-1953, scale 1:24,000.

O'Sullivan, R.B., Wahl-Pierce, Frances, and Arbelbide, S.J., 1981, Preliminary geologic map of the McCarthy Gulch quadrangle, Rio Blanco and Garfield Counties, Colorado: U.S. Geological Survey Miscellaneous Field Studies Map MF-860, scale 1:24,000.

Pitman, J.K., 1979, Isopach, structure contour, and resource maps of the R-6 oil shale zone, Green River Formation, Piceance Creek basin, Colorado: U.S. Geological Survey Miscellaneous Field Studies Map MF-1069, scale $1: 126,720$.

Pitman, J.K., and Donnell, J.R., 1973, Potential shale-oil resources of a stratigraphic sequence above the Mahogany zone, Green River Formation, Piceance Creek basin, Colorado: U.S. Geological Survey Journal of Research, v. 1, no. 4, p. $467-473$.

Pitman, J.K., and Johnson, R.C., 1978, Isopach, structure contour, and resource maps of the Mahogany oil shale zone, Green River Formation, Piceance Creek basin, Colorado: U.S. Geological Survey Miscellaneous Field Studies Map MF-958, scale 1:126,720.

Pitman, J.K., Wahl-Pierce, Frances, and Grundy, W.D., 1989, Thickness, oil-yield, and kriged resource estimates for the Eocene Green River Formation, Piceance Creek Basin, Colorado: U.S. Geological Survey Oil and Gas Investigations Chart OC-132.

Rio Blanco Oil Shale Project, 1976, Detailed development plan Tract C-a: Submitted to U.S. Geological Survey, v. 2, ch. 3, $73 \mathrm{p}$.

Trudell, L.G., Beard, T.N., and Smith, J.W., 1970, Green River Formation lithology and oil-shale correlations in the Piceance Creek basin, Colorado: U.S. Bureau of Mines Report of Investigations 7357, $14 \mathrm{p}$.

Tweto, Ogden, Moench, R.H., and Reed, J.C., Jr., 1978, Geologic map of the Leadville $1^{\circ} \times 2^{\circ}$ quadrangle, northwestern Colorado: U.S. Geological Survey Miscellaneous Investigations Series Map I-999, scale 1:250,000.

Waldron, F.R., Donnell, J.R., and Wright, J.C., 1951, Geology of the DeBeque oil-shale area, Garfield and Mesa Counties, Colorado: U.S. Geological Survey Oil and Gas Investigations Map OM-114.

Ziemba, E.A., 1974, Oil shale geology, Federal tract C-a, Rio Blanco County, Colorado, in Guidebook to the energy resources of the Piceance Creek basin, Colorado: Rocky Mountain Association of Geologists Annual Field Conference, 25th, p. 123-129. 


NORTH
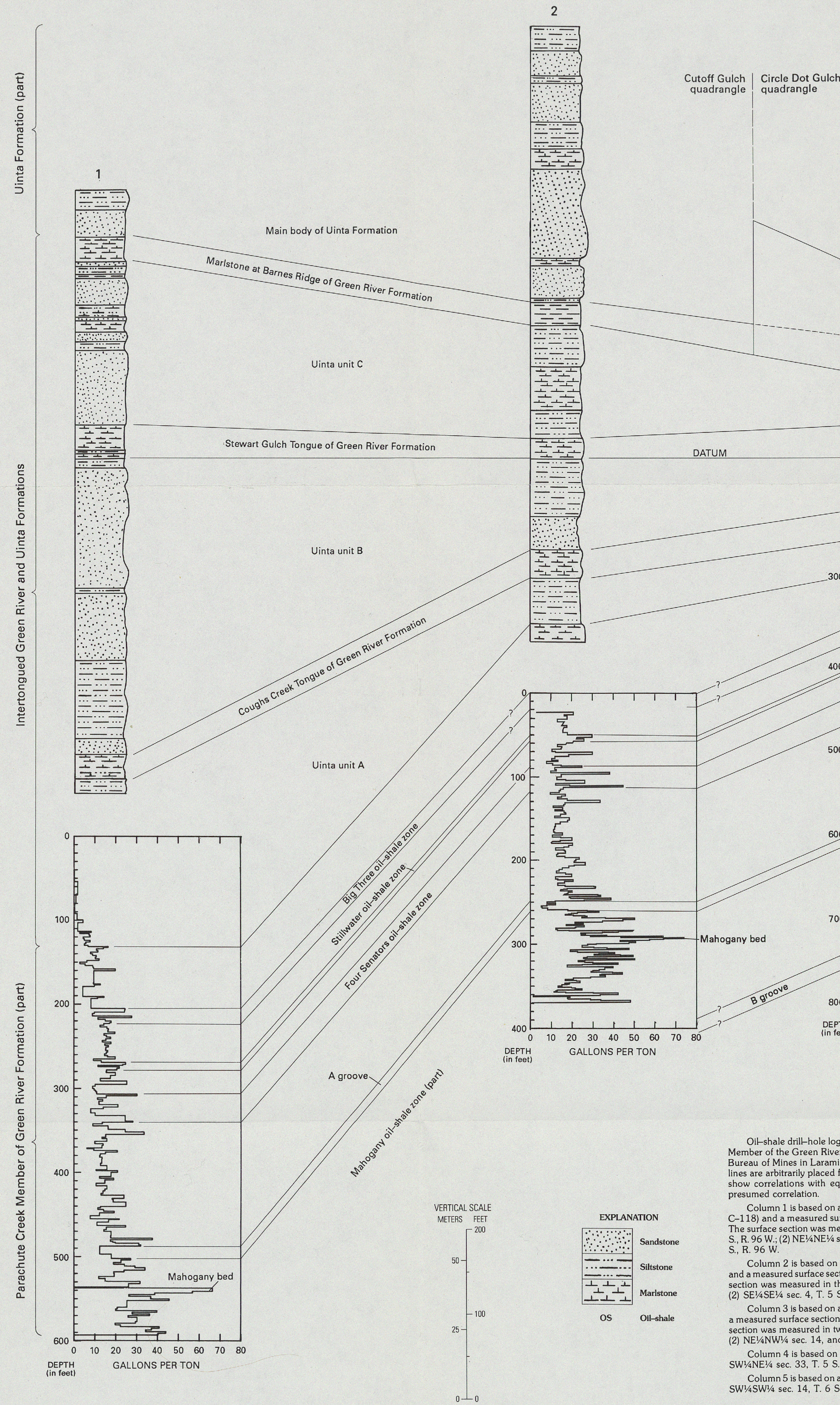

CORRELATION OF SELECTED STRATIGRAPHIC UNITS OF EOCENE GREEN RIVER AND UINTA FORMATIONS IN THE EASTERN PART OF THE CENTRAL ROAN PLATEAU AREA, NORTHWESTERN COLORADO 



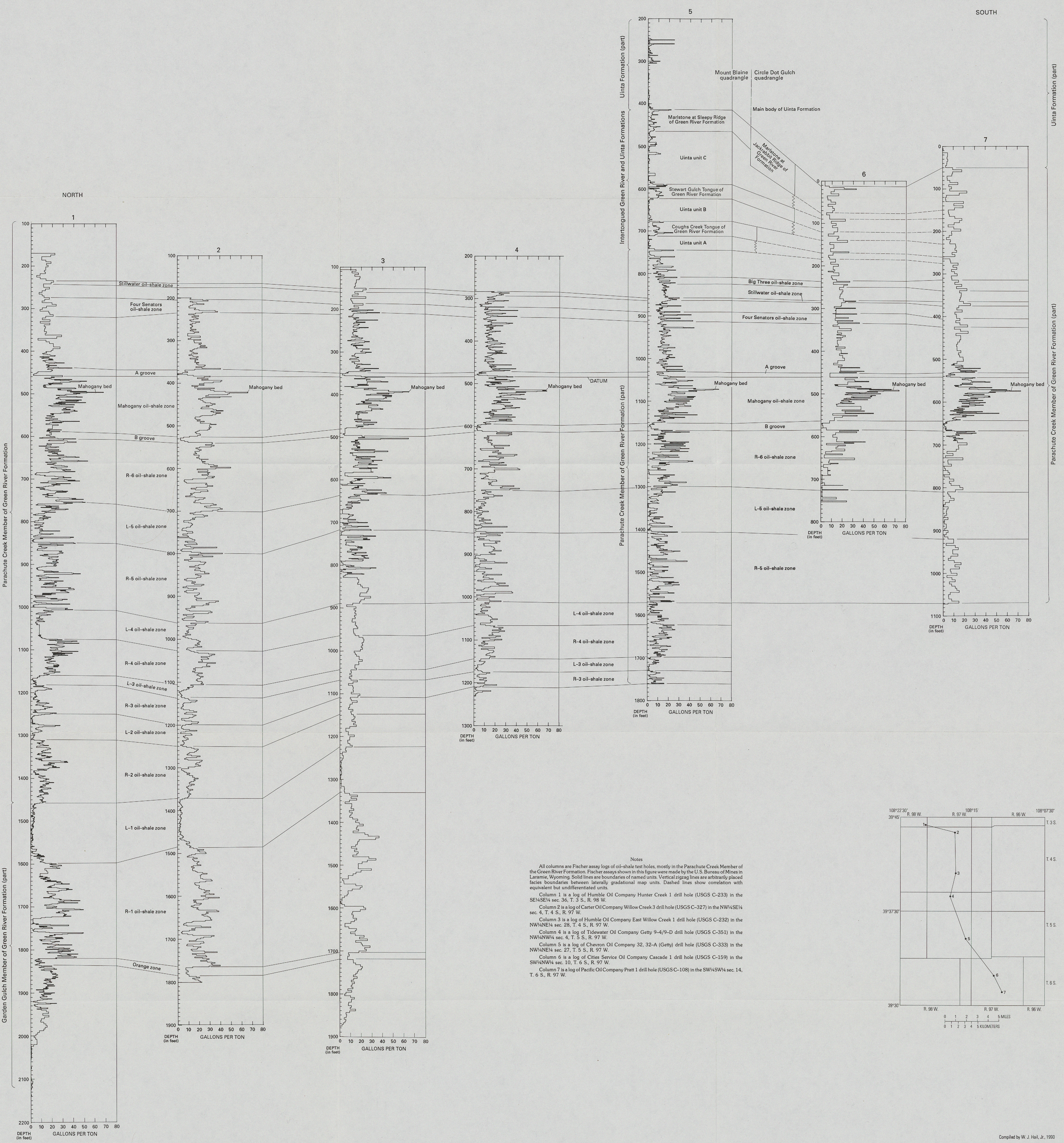


